
the Processing of Hanford Site Cesium and Strontium Isotopic Sources in the Hanford Waste Vitrification Plant

Prepared for the U.S. Department of Energy Office of Environmental Restoration and Waste Management

(20) Westinghouse

Hantord Operations and Engineering Contractor for the

U.S. Department of Energy under Contract DE-AC06-87AL 10930 


\section{LEGAL DISCLAMEA}

This report was prepared as an account of work sponsored by an agency of the United States Government. Neither the

United States Government nor any agency thereof, nor any of their employees, nor any of their contractors, subcontractors or their employees, makes any warranty, express or implied, or assumes any legal liability or responsibility for the accuracy, completeness, or any third party's use or the results of such use of any information, apparalus, product, or process disclosed, or represents that its use would not iniringe privately owned rights. Relerence herein to any specific commercial product, process, or service by trade name, trademark, manufacturer, or otherwise, does not necessarily constitute or imply its endorsement, recommendation, or favoring by the United States Government or any agency thereof or its contractors of subcontractors. The views and opinions of authors expressed herein do nol necessarily state or reflect those of the United States Government or any agency thereof.

This repon has been reproduced from the best available copy. Available in paper copy and microfiche.

Available to the U.S. Department of Energy

and its contractors from

Office of Scientific and Technical Information

P.O. Box 62

Oak Ridge, TN 37831

(615) 576.8401

Available to the public from the U.S. Department of Commerce National Technical Information Service

5285 Port Royal Road

Springfield. VA 22161

(703) $487-4650$

Printed in the Unitod States of America

DISCLM-1.CHP (1-DI) 


\section{DISCLAIMER}

Portions of this document may be illegible in electronic image products. Images are produced from the best available original document. 


\section{Feasibility Study for the Processing of Hanford Site Cesium and Strontium Isotopic Sources in the Hanford Waste Vitrification Plant}

R. P. Anantatmula

R. A. Watrous

J. L. Nelson

Westinghouse Hanford Company

J. M. Perez

R. D. Peters

M. E. Peterson

Pacific Northwest Laboratory

Date Published

September 1991

Prepared for the U.S. Department of Energy Office of Environmental Restoration and Waste Management

(2) Westinghouse P.O. Box 1970

(W) Hantord Company Richland, Washington 99352

Hantord Operations and Engineering Contractor for the

U.S. Department of Energy under Contract DE-AC06-87AL.10930

Approved for Public Release 


\section{RELEASE AUTHORIZATION}

\section{Document Number: WHC-EP-0460}

$\begin{array}{ll}\text { Feasibility Study for the Processing of Hanford Site } \\ \text { Document Title: } & \text { Cesium and Strontium Isotopic Sources in the Hanford }\end{array}$ Waste Vitrification Plant

Release Date: $\quad 9 / 20 / 94$

This document was reviewed following the procedures described in WHC-CM-3-4 and is:

APPROVED FOR PUBLIC RELEASE

**************

WHC Information Release Administration Specialist:

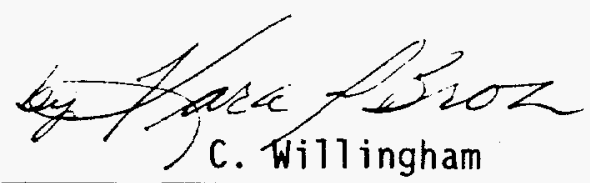

(Signature) $9 / 20 / 94$

(Date) 


\section{EXECUTIVE SUMHARY}

The final environmental impact statement for the disposal of defenserelated wastes at the Hanford Site (Final Environmental Impact Statement: Disposal of Hanford Defense High-Level, Transuranic and Tank Wastes [HDW-EIS] [DOE 1987]) states that the preferred alternative for disposal of cesium and strontium wastes at the Hanford Site will be to package and ship these wastes to the commercial high-level waste repository. The Record of Decision for this EIS states that before shipment to a geologic repository, these wastes will be packaged in accordance with repository waste acceptance criteria. However, the high cost per canister for repository disposal and uncertainty about the acceptability of overpacked capsules by the repository suggest that additional alternative means of disposal be considered. Vitrification of the cesium and strontium salts in the Hanford Waste Vitrification Plant (HWVP) has been identified as a possible alternative to overpacking. Subsequentiy, Westinghouse Hanford Company's (Westinghouse Hanford) Projects Technical Support office undertook a feasibility study to determine if any significant technical issues preclude the vitrification of the cesium and strontium salts.

Based on the information presented in this report, it is considered technically feasible to blend the cesium chloride and strontium fluoride salts with neutralized current acid waste (NCAW) and/or complexant concentrate (CC) waste feedstreams, or to blend the salts with fresh frit and process the waste through the HWVP. In addition, based on a rough order-of-magnitude cost estimate, blending the capsules either directly or removing the hal ides before blending with NCAW and/or CC waste is the least-cost alternative when compared to overpacking the capsules and shipping them to the repository. In the 
absence of any viable programmatic missions for the long-term beneficial use of the intact capsules, three scenarios are considered for handling the cesium and strontium capsules: (1) vitrify the cesium and strontium waste in the HWVP and ship the canistered waste to the repository, (2) store the capsules at the Hanford Site for an indefinite period (the no-disposal action required by the National Environmental Policy Act), and (3) overpack the capsules and ship them to the repository. This study focuses on the first scenario. Limited evaluations were performed on the second and third scenarios for comparison with processing through the HWVP.

Processing the capsules through the HWVP appears to produce a borosilicate glass waste form that will comply with the disposal requirements for high-level waste as promulgated in 10 CFR 60 . However, demonstration of compliance with the radionuclide release limits will require additional study to verify that cesium release limits will not be exceeded. Additionally, flowsheet testing will be necessary to demonstrate acceptable processing characteristics.

Several options exist for processing the capsule waste at WESF to produce a waste feed stream acceptable to HWVP: (1) do not perform any chemical separation and prepare the waste either for blending with NCAW and/or CC waste or for vitrification as a separate HWVP feed stream and (2) remove the halides from the cesium chloride and strontium fluoride before blending with NCAW and/or CC waste, or vitrify as a separate HWVP feed stream. The options are shown in flowsheet fashion in Figure S-1. Unit costs are given for each step within the boxes. Total costs are provided at the upper corner of the last box for each option. The lowest cost option would be to blend the capsule 
Figure S-1. Options and Estimated Costs for Cesium and Strontium Capsule Vitrification.

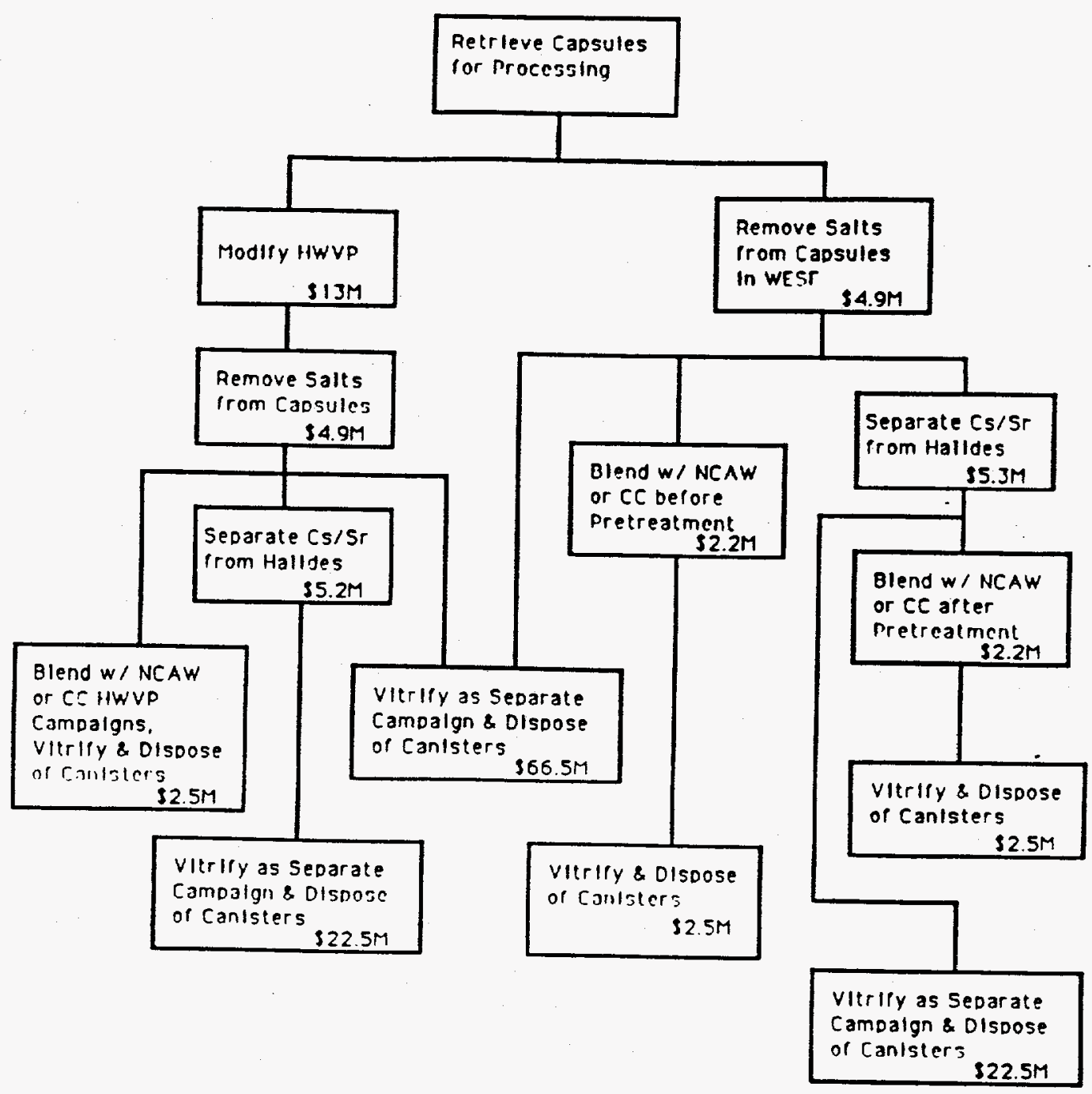


material directly into NCAW and/or CC waste before pretreatment. A relative order-of-magnitude cost of $\$ 9.6$ million has been estimated for this option. Separation of the halides from the cesium and strontium, followed by blending with NCAW and/or CC waste, is the lowest cost option at $\$ 14.9$ million. If a separate HWVP campaign is required, costs are estimated to vary from $\$ 32.7$ million to $\$ 71.4$ million, depending on whether or not the halides are removed before vitrification.

With appropriate modification to either or both facilities, the capsules can be processed in the Waste Encapsulation and Storage Facility (WESF) or HWVP. However, at the present time, availability of space for capsule processing at WESF appears questionable because of competing projects such as the Transuranic Extraction (TRUEX) pilot-plant testing and the HWV benchscale melter testing. Processing the capsules at the HWVP would require modifications to the HWVP; the modifications are estimated to increase the HWVP design and construction costs by $\$ 13$ million. Including these costs into the overall costs, the costs for HWVP, vitrification, and final canister disposal will range between $\$ 20.4$ million and $\$ 84.5$ million (see figure $S-1$ ).

Continued long-term storage of the capsules until the cesium and strontium decay to sufficiently low levels is significantly more expensive (the estimated cost is $\$ 6.1$ billion) than processing the capsules through the HWVP. This scenario requires construction of a new facility or modification to an existing facility and operation of the facility for approximately $300 \mathrm{yr}$. The operation includes continuous monitoring of the capsules to ensure isolation from the environment. 
The overpacking concept will not comply with the regulatory requirements for chemical and phase stability defined by Chapter 10 of Code of Federal Regulations (10 CFR) 60.135 (a)(2) or chemical compatibility defined by 10 CFR $60.135(a)(1)$. Thus, it will not be possible to dispose of the overpacked cesium and strontium capsules without seeking a waiver for at least these two repository disposal requirements.

As a result of the combined technical and economic advantages of vitrifying the cesium and strontium salts, it is recommended that an engineering study be performed to more thoroughly evaluate vitrification of the capsule waste in the HWVP. In parallel with this study, regulatory and repository issues should be more fully investigated and documented. 
1.0 INTRODUCTION AND SCOPE ................. . . 1-1

1.1 INTRODUCTION ........................ 1 . . . .

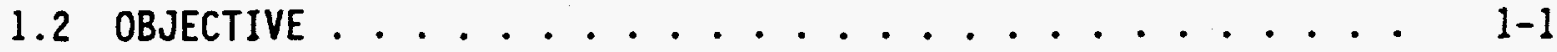

2.0 ASSUMPTIONS AND REQUIREMENTS ................. 2-1

2.1 ASSUMPTIONS ....................... $2-1$

2.2 REQUIREMENTS ....................... 2-1

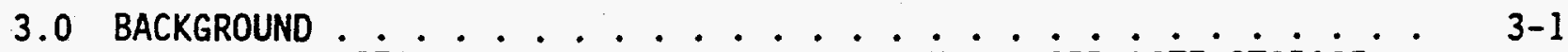

3.1 INDEFINITE STORAGE OF THE CAPSULES IN HANFORD SITE STORAGE

BASINS (NO DISPOSAL ACTION)

3.2 OVERPACK CAPSULES AND SEND TO REPOSITORY ........ $3-1$

3.2.1 Waste Acceptance Prel iminary Specification 1.3:
Specification for Radionuclide Release Properties . . 3-2

3.2.2 Waste Acceptance Preliminary Specification 1.4:

Chemical and Phase Stability (10 CFR 60.135[a] [2]
3.2.3 Waste Acceptance Prel iminary Specification 3.9:

Chemical Compatibility (10 CFR 60.134[a][1]) . . . 3-5

4.0 EVALUATION OF HWVP PROCESSING CONSIDERATIONS . . . . . . . . . 4-1

4.1 GLASS COMPOSITION AND PROCESSABILITY . . . . . . . . . . 4-1

4.2 GLASS DURABILITY . . . . . . . . . . . . . . . . . 4-4

4.3 RADIATION THERMAL LOADING ............. . . 4-4

4.4 OFFGAS VOLATILITY AND TREATMENT . . . . . . . . . 4-5

4.5 EQUIPMENT MATERIALS COMPATIBILITY . . . . . . . $4-8$

5.0 PROCESS DESCRIPTIONS FOR HALIDE SEPARATION ......... . 5-1

5.1 BACKGROUND . . . . . . . . . . . . . 5-1

5.2 SEPARATION OF CHLORIDE FROM CESIUM CHLORIDE ....... 5 5-1

5.2.1 Ion Exchange . . . . . . . . . . 5-1

5.2.2 Reaction with Silver Nitrate . . . . . . . . 5-3

5.3 SEPARATION OF FLUORIDE FROM STRONTIUM FLUORIDE . . . . . 5-3

5.3.1 Acid Decomposition of Strontium Fluoride . . . . . . 5-3

5.3.2 Metathesis of Strontium Sulfate to Strontium
Carbonate . . . . 5 . . . . . . . . .

5.3.3 Dissolution of Strontium Carbonate in Nitric Acid . 5-5

6.0 EVALUATION OF FACILITIES AND EQUIPMENT ........ . . . . . .

6.1 BLEND CESIUM CHLORIDE AND STRONTIUM FLUORIDE DIRECTLY

WITH NEUTRALIZED CURRENT ACID WASTE AND/OR COMPLEXANT

CONCENTRATE WASTE .................. 6- $6-2$

6.1.1 Dismantling of Cesium Chloride Capsules . . . . . . 6-2

6.1.2 Dismantling of Strontium Fluoride Capsules . . . . . 6-3

6.1.3 Blending of Cesium Chloride and Strontium Fluoride

Solutions with Neutralized Current Acid Waste

and/or Complexant Concentrate Waste and Transfer

to Hanford Waste Vitrification Plant . . . . . . . 6-4 


\section{CONTENTS (cont)}

6.2 PRETREATMENT OF CESIUM CHLORIDE AND STRONTIUM FLUORIDE

BEFORE BLENDING WITH NEUTRALIZED CURRENT ACID WASTE AND/OR

COMPLEXANT CONCENTRATE WASTE ............... 6- 6-5

6.2.1 Separation of Chloride from Cesium Chioride . . . . . 6-5

6.2.2 Separation of Fluoride from Strontium Fluoride... . 6-10

6.2.3 Blending of Cesium Nitrate and Sodium Nitrate

Solutions with Neutralized Current Acid Waste and/or

Complexant Concentrate Waste and Transfer to the

Hanford Waste Vitrification Plant . . . . . . . 6-13

6.3 HANFORD WASTE VITRIFICATION PLANT FACILITIES AND

REQUIRED MODIFICATIONS ................. 6-13

7.0 COST ESTIMATES . . . . . . . . . . . . . . . . . . . 7-1

7.1 INDEFINITE STORAGE OF CAPSULES . . . . . . . . . . . . . . . $7-1$

7.2 OVERPACK THE CAPSULES AND SHIP TO REPOSITORY . . . . . . . . . $7-1$

7.3 PROCESS CAPSULES THROUGH THE HANFORD WASTE

VITRIFICATION PLANT .................... . . . . . -

7.3.1 BTend Cesium Chioride and Strontium Fluoride Directly

with Neutralized Current Acid Waste and/or

Complexant Concentrate Waste ............ 7-1

7.3.2 Pretreatment of Cesium Chloride and Strontium

Fluoride Before Blending with Neutralized Current

Acid Waste and/or Complexant Concentrate Waste . . . 7-4

7.3.3 Hanford Waste Vitrification Plant Campaign

Specifically for Capsules . . . . . . . . . . . 7-6

7.3.4 Modify Hanford Waste Vitrification Plant for Capsule

Handling and Processing ............. . . 7-7

8.0 SCHEDULE . . . . . . . . . . . . . . . . . . . . 8-1

9.0 REFERENCES . . . . . . . . . . . . . . . . . . . 9-1

Appendixes:

A. REQUIREMENTS FOR REPOSITORY DISPOSAL OF DEFENSE HIGHLEVEL WASTE ......................... A-1

B. EFFECTS OF CESIUM CHLORIDE AND STRONTIUM FLUORIDE CAPSULE ADDITION TO NEUTRALIZED CURRENT ACID WASTE GLASS . . . . . . B-1

C. EFFECTS OF CESIUM CHLORIDE AND STRONTIUM FLUORINE CAPSULE ADDITION TO COMPLEXANT CONCENTRATE GLASS . . . . . . . . . C 1 
WHC-EP-0460

\section{LIST OF FIGURES}

4-1 Rate of Decay of Neutralized Current Acid Waste Canister Radionuclides . . . . . . . . . . . . . 4-6

4-2 Effects of Canister Watt Loading on Canister Centerline Temperature ..................... . 4 4-7

5-1 Flowsheet and Mass Balance for Ion Exchange Dechlorination of Cesium Chloride .. . . . . . . . . . . . . . . . 5-2

5-2 Flowsheet and Mass Balance for the Removal of Chloride Ion from Cesium Chloride Solution by Precipitation with Silver Nitrate................... . . . 5-4

5-3 Flowsheet for the Acid Decomposition of Strontium Fluoride . . . 5-6

5-4 Flowsheet for the Metathesis of Strontium Sulfate to Strontium Carbonate .................... 5-8

6-1 Flow Diagram for Ion-Exchange Dechlorinization of Cesium Chloride .................... . 6-6

6-2 Flow Diagram for Processing Cesium Chloride to Remove Chloride . . 6-8

6-3 Schematic of Filter System for Separating Silver Chloride from Cesium Nitrate. . . . . . . . . . . . . . . . . . 6-9

6-4 Flow Diagram for Processing Strontium Fluoride to Remove Fluoride ............... 6-11

8-1 Schedule for Blending the Capsules with Neutralized Current Acid Waste :. . . . . . . . . . . . . . . 


\section{LIST OF TABLES}

3-1 Waste Acceptance Preliminary Specifications for the Defense

Waste Processing Facility High-Level Waste Form ... . . . . 3-3

4-1 Limits for Chlorine and Fluorine in the Glass Form . . . . . . 4-2

5-1 Mass Balance for the Acid Decomposition of Strontium Fluoride . . . 5-7

5-2 Mass Balance for the Metathesis of Strontium Sulfate to Strontium Carbonate ............... 5-9

7-1 Cost Estimate for the Equipment Required for Processing Cesium Chloride and Strontium Fluoride at the Waste Encapsulation and Storage Facility for Direct Blending with Neutralized Current Acid Waste and/or Complexant Concentrate Waste ........ 7-2

7-2 Cost Estimate for the Equipment Required to Separate the Halides from Cesium Chloride and Strontium Fluoride at the Waste Encapsulation and Storage Facility Before Blending with Neutralized Current Acid Waste and/or Complexant Concentrate Waste .............. 7-5

7-3 Cost Estimate for the Chemicals Required to Separate the Halides from Cesium Chloride and Strontium Fluoride . . . . . . 7-6 


\section{ACROHYMS}

ANSI

CC

CFR

DF

DOE

DWPF

EA

FRG

FY

HEPA

HDW-EIS

HWVP

NCAW

NCRW

NEPA

OCRWM

OGR

ORNL

PCT

PFP

PHP

PNL

RLFCM

RLST

ROD

SAR

SARP

SRAT

TDP

TPA

TRUEX

WAC

WAPS

WCD

WESF

Westinghouse Hanford
American National Standards Institute

complexant concentrate

U.S. Code of Federal Regulations

decontamination factor

Department of Energy

Defense Waste Processing Facility

Environmental Assessment

Federal Republic of Germany

fiscal year

high-efficiency particulate air

Hanford Defense Waste-Environmental Impact Statement Hanford Waste Vitrification Plant neutralized current acid waste neutralized cladding removal waste National Environmental Policy Act

Office of Civilian Radioactive Waste Management Office of Geologic Repositories

Oak Ridge National Laboratory

Product Consistency Test

Plutonium Finishing Plant

pneumatic hydropulse

Pacific Northwest Laboratory

radioactive liquid-fed ceramic melter

receipt and lag storage tank

Record of Decision

Safety Analysis Report

Safety Analysis Report for Packaging

slurry receipt and adjustment tank

HWVP Technical Data Package

Tri-Party Agreement

Transuranic Extraction

Washington Administrative Code

Waste Acceptance Preliminary Specifications

waste form and canister description

Waste Encapsulation and Storage Facility

Westinghouse Hanford Company 
WHC-EP-0460

\section{FEASIBILITY STUDY FOR THE PROCESSING OF HANFORD WASTE VITRIFICATION PLANT CESIUH AND STRONTIUN ISOTOPIC SOURCES}

\subsection{INTRODUCTION AND SCOPE}

\subsection{INTRODUCTION}

Disposal options for cesium- and strontium-containing capsules at the Hanford Site were first put forth in the Final Environmental Impact Statement: Disposal of Hanford Defense High-Level, Transuranic and Tank Wastes (HDW-EIS) (DOE 1987). The associated Record of Decision (ROD) stated that the capsules will be packaged in accordance with repository waste acceptance criteria and sent to the federal high-level waste repository for disposal. It is quite probable, however, that a simple capsule overpacking concept will not be judged an acceptable waste form because of concerns about radionuclide solubility and chemical compatibility. This issue must be resolved with the repository program. In the meantime, it was considered prudent to initiate a formal feasibility study of the disposal of radioactive cesium and strontium by vitrification as an alternative to overpacking. This approach seems reasonable in view of plans for the Hanford Waste Vitrification Plant (HWVP) and the acceptance of borosilicate glass as a waste form.

This study assesses the feasibility of treating and disposing of encapsulated cesium and strontium waste by incorporating the capsule contents into wastes slated to be processed in the HWVP or by vitrifying the capsules as a new HWVP feed stream. In making this assessment, alternative options for storage, treatment, and disposal have been considered briefly. Subsequent analysis will be required to determine whether the recommended disposal option falls within the scope of the existing ROD and to document any potential changes from the ROD.

\subsection{OBJECTIVE}

The objective of this study is to determine whether significant technical issues would preclude the incorporation of encapsulated cesium and strontium wastes into the waste streams to be processed by the HWVP. To make this determination, it is necessary to evaluate the impact of the capsule contents on the major process steps within the HWVP and to define the capsule-handling and potential pretreatment steps required to blend the cesium chloride (CsCl) and strontium fluoride $\left(\mathrm{SrF}_{2}\right)$ with the HWVP wastes.

The study intends to establish the feasibility of vitrifying the $\mathrm{CsCl}$ and $\mathrm{SrF}_{2}$ in the HWVP. The impacts of CsCl and $\mathrm{SrF}_{2}$ addition on the HWVP process conditions and waste form characteristics have been assessed. Two additional alternatives for disposal of the capsule salts are considered briefly:

(1) continuing to store the capsules in the storage basins indefinitely, that is, until the cesium and strontium decay to low levels (the no-disposal action required by the National Environmental Policy Act [NEPA] process); and (2) overpacking the capsules and sending them to the repository for permanent disposal. 
WHC-EP-0460

This page intentionally left blank. 


\subsection{ASSUMPTIONS AND REQUIREMENTS}

The assumptions and technical requirements used for this study are described in this section. They have been derived from the Hanford Waste Vitrification Plant Technical Data Package (WHC 1989), waste acceptance specifications for repository waste forms, and knowledge of the vitrification process and waste management practices.

\subsection{ASSUMPTIONS}

It has been assumed that the cesium and strontium capsules will be returned to the Hanford Site following expiration of current lease agreements. (Discussions with responsible Hanford Site and Oak Ridge National Laboratory [ORNL] offices have concluded that no long-term missions exist for the capsules beyond the current lease agreements.) Therefore, all capsules are assumed to be onsite by the time the HWVP begins operations with radioactive waste. Cells and capabilities within the Waste Encapsulation and Storage Facility (WESF)/B Plant facility or the HWVP are assumed to be available for initial processing of the capsules. It has also been assumed that, for whatever steps are taken, the final waste form must meet requirements from 10 CFR 60 and 40 CFR 191 for disposal of the capsule waste in the federal high-level waste repository. Existing facilities on the Hanford Site or the HWVP itself must be capable of handling the capsules and removing the cesium and strontium for blending with HWVP feedstreams. This capability may require modifications to existing facilities, which will be described in this report.

\subsection{REQUIREMENTS}

For the cesium and strontium to be processed within the HWVP, the following requirements must be satisfied:

- The final waste form must still meet the repository waste acceptance specifications for borosilicate glass.

- Processing in the HWVP should not be impacted such that equipment failures and process rates below the design criteria of $100 \mathrm{~kg} / \mathrm{h}$ glass production occur.

- Environmental releases of radioactive or hazardous materials should not exceed allowable standards set for the HWVP. 
$W H C-E P-0460$

This page intentionally left blank. 


\subsection{BACKGROUND}

This study focuses on the feasibility of vitrifying the capsule waste in the HWVP. Two additional alternatives are described here to provide background information: (1) storing the capsules in the Hanford Site storage basins indefinitely, and (2) overpacking the capsules and sending them to the high-level waste geologic repository. Limited evaluations for these two alternatives were performed to enable a comparison with the alternative of processing the capsule waste in the HWVP.

\subsection{INDEFINITE STORAGE OF THE CAPSULES IN HANFORD SITE STORAGE BASINS (NO DISPOSAL ACTION)}

Facilities currently exist at the WESF on the Hanford Site for temporary storage of the capsules. The capsules could be stored for $30 \mathrm{yr}$ or more at WESF. Corrosion data from Bryan (1987) indicate that attack from CsCl at the storage temperatures will be very low, so capsule containment should last for at least 30 or $40 \mathrm{yr}$, perhaps up to several hundred years. However, recent episodes of capsule failure during irradiator service have occurred. Longterm storage may require placement of additional containment around all capsules at a cost of about $\$ 10,000$. Operation of WESF requires that the connecting B Plant also operate, but the missions envisioned for $B$ Plant do not extend beyond the year 2005. Therefore, either WESF must be modified to operate independently or a new stand-alone facility must be constructed for indefinite storage of the capsules.

Long-term storage of the capsules is not likely to be considered institutionally viable because the Hanford Federal Facility Agreement and Consent Order (Ecology et al. 1990) (Tri-Party Agreement) calls for removal and permanent disposal of high-level radioactive wastes stored at the Hanford Site. Furthermore, the ROD for the HDW-EIS requires disposal of these capsules. A supplemental EIS may be required to reverse this decision, and public acceptance of such a reversal is questionable. Therefore, continued storage at WESF or at a stand-alone facility is considered only as an interim step until the capsules can be processed for permanent disposal.

\subsection{OVERPACK CAPSULES AND SEND TO REPOSITORY}

The HDW-EIS (DOE 1987) presents this scenario as the preferred alternative for disposal of cesium and strontium capsules. The same alternative is also described as the preferred plan in the Hanford Waste Management Plan (DOE-RL 1987). This preferred option for disposal calls for the capsules to be overpacked into canisters suitable for placement in the high-level waste repository. In this plan, up to four intact capsules would be placed in a canister of the same external dimensions as used by the HWVP. The characteristics of the HWVP canister are documented in the Hanford Waste Vitrification Plant Preliminary Waste Form and Canister Description--Fiscal Year 1990 Update (Colburn 1990). The internal structure of the canister would be modified to restrain the capsules and to provide heat transfer to the canister walls. Modifications to existing facilities (such as WESF) on the Hanford Site may be required to overpack the capsules. 
In JuTy 1985, the U.S. Department of Energy's (DOE) Office of Civilian Radioactive Waste Management (OCRWM) established a waste acceptance process as the means by which high-level waste producers would be allowed to dispose of wastes in the commercial repository. The waste acceptance process is generic because it is intended to accommodate any high-level waste form other than spent fuel. The Waste Acceptance Preliminary Specifications (WAPS) are based on the waste form and canister description (WCD). The waste acceptance process requires that OCRMM prepare WAPS's for each waste form. The WAPS's will be prepared for the cesium and strontium capsule waste form once the WCD is issued.

The WAPS's for borosilicate glass have been drafted and are currently in review. Although these WAPS's are tailored for borosilicate glass, much of their.bases derive from the U.S. Code of Federal Regulations (CFR) or limitations to repository handling capability. Appendix $A$ discusses the bases for waste acceptance requirements for borosilicate glass waste forms. Because the existing WAPS's are based on regulatory requirements or repository design constraints, they provide useful guidance for the development of nonborosilicate glass waste forms. The WAPS's for the Defense Waste Processing Facility (DWPF) are summarized in Table 3-1 (from DOE 1989). Of the 21 individual specifications shown in Table 3-1, all but 3 can be accommodated in the capsule overpack concept. A discussion of the three problematic specifications follows.

\subsubsection{Waste Acceptance Preliminary Specification 1.3: Specification for Radionuclide Release Properties}

The current reference version of the WAPS's for the DWPF stipulates that the waste form must have a normalized release limit for certain matrix elements and radionuclides of less than $1 \mathrm{~g} / \mathrm{m}^{2}$-d averaged over the 28-d MCC-1 test. Although a draft revision to this specification would change the test protocol, the changes, if adopted, would not affect the conclusion herein (see Section 4.2, "Glass Durability").

Most investigators agree that glass dissolution results from the associated matrix dissolution of silica. Testing with simulated NCAW glass has shown cesium release to be within a factor of two times greater than silica. Strontium release is less than silica (Goles and Nakaoka 1990). If it is assumed that waste $\mathrm{glass}$ has a $1 \mathrm{~g} / \mathrm{m}^{2}-\mathrm{d}$ release rate and that this is related to the solubility of silica (i.e., release rate is proportional to solubility), then a comparison between $\mathrm{CsCl}_{1}, \mathrm{SrF}_{2}$, and waste glass can be made by virtue of solubility. The aqueous solubility of amorphous silica, or waste glass in this case, is $50 \mathrm{mg}$ of silicon/L at room temperature (Fournier and Rowe 1977). The room temperature solubility of $\mathrm{CsCl}$ is $1,300 \mathrm{mg}$ of cesium/L, and for $\mathrm{SrF}_{2}$ it is $85 \mathrm{mg}$ of strontium/L (Weast 1987). Clearly, CsCl is much worse than glass in terms of matrix solubility and would likely not be acceptable as a waste form. The solubility of $\mathrm{SrF}_{2}$ is much closer to that of silica, but still higher by almost a factor of two. Release rates from $\mathrm{SrF}_{2}$ may be marginally acceptable, but a more detailed analysis will be needed. 
Table 3-1. Waste Acceptance Preliminary Specifications for the Defense Waste Processing Facility High-Level Waste Form. (sheet 1 of 2)

\begin{tabular}{|c|c|c|}
\hline \multicolumn{2}{|r|}{ Specification } & Content summary \\
\hline 1.1 & Chemical composition & $\begin{array}{l}\text { Provide projection of product elemental and } \\
\text { phase compositions (with ranges) for } 7 \text { ife of } \\
\text { facility for all elements in concentrations } \\
>0.5 \text { wt\%. }\end{array}$ \\
\hline 1.2 & $\begin{array}{l}\text { Radionuclide } \\
\text { inventory }\end{array}$ & $\begin{array}{l}\text { Provide canister and aggregate inventories of } \\
\text { all radionuclides with half- } 1 \text { ife periods longer } \\
\text { than } 10 \text { yr with concentrations }>0.05 \mathrm{Ci} \text { at any } \\
\text { time up to } 1,100 \mathrm{yr} \text { after production. }\end{array}$ \\
\hline 1.3 & Radionuclide release & $\begin{array}{l}\text { Production samples must show normalized } \\
\text { releases of }<1 \mathrm{~g} / \mathrm{m}^{2}-d \text { for } \mathrm{MCC}-1 \text { tests or } \\
\text { equivalent. }\end{array}$ \\
\hline 1.4 & $\begin{array}{l}\text { Chemical and phase } \\
\text { stability }\end{array}$ & $\begin{array}{l}\text { Report product transition temperature and time- } \\
\text { temperature-transformation ranges. Certify } \\
\text { that waste form has not exceeded transition } \\
\text { temperature during storage and is at least } \\
100{ }^{\circ} \mathrm{C} \text { below transition temperature at } \\
\text { shipment. }\end{array}$ \\
\hline 2.1 & Canister material & Austenitic stainless steel. \\
\hline 2.2 & $\begin{array}{l}\text { Canister fabrication } \\
\text { and closure }\end{array}$ & Leaktight according to ANSI ${ }^{\circ}$ N14.5-1977. \\
\hline 2.3 & $\begin{array}{l}\text { Identification and } \\
\text { labeling }\end{array}$ & $\begin{array}{l}\text { A)phanumeric code on each canister visible from } \\
\text { top or side of canister. Characters at least } \\
92 \text { points in height. }\end{array}$ \\
\hline 3.1 & Free 1 iquid & None allowed in canister. \\
\hline 3.2 & Gases & $\begin{array}{l}\text { None allowed in canister except helium, argon, } \\
\text { air, or other inerts. Internal pressure not to } \\
\text { exceed } 7 \mathrm{lb} / \mathrm{in}^{2} \text { (gage) at } 25^{\circ} \mathrm{C} \text {. }\end{array}$ \\
\hline 3.3 & $\begin{array}{l}\text { Explosiveness, } \\
\text { pyrophoricity, and } \\
\text { combustibility }\end{array}$ & $\begin{array}{l}\text { No explosive, pyrophoric, or combustible } \\
\text { materials allowed in canister. }\end{array}$ \\
\hline 3.4 & Organic materials & None allowed in canister. \\
\hline 3.5 & Free volume & Less than $20 \%$ of canister volume. \\
\hline 3.6 & $\begin{array}{l}\text { External } \\
\text { contamination }\end{array}$ & $\begin{array}{l}\text { Less than } 220 \text { alpha } \mathrm{dpm} / 100 \mathrm{~cm}^{2} \text {. Less than } \\
2,200 \text { beta-gamma dpm/100 } \mathrm{cm}^{2} \text {. }\end{array}$ \\
\hline 3.7 & Heat generation & $\begin{array}{l}\text { Less than } 800 \mathrm{~W} / \text { canister reported to } \pm 15 \% \text {. } \\
\text { Provide projections and actuals. }\end{array}$ \\
\hline 3.8 & Maximum dose rate & $\begin{array}{l}\text { Less than } 10^{5} \text { rem } / \mathrm{h} \text { gamma and } 10^{3} \text { rem } / \mathrm{h} \text { neutron } \\
\text { at surface. Provide projections and actuals. }\end{array}$ \\
\hline
\end{tabular}


Table 3-1. Waste Acceptance Prel iminary Specifications for the Defense Waste Processing Facility High-Level Waste Form. (sheet 2 of 2)

\begin{tabular}{|c|c|c|}
\hline \multicolumn{2}{|r|}{ Specification } & Content summary \\
\hline 3.9 & $\begin{array}{l}\text { Chemical } \\
\text { compatibility }\end{array}$ & $\begin{array}{l}\text { Document reactivity between waste form and } \\
\text { canister. }\end{array}$ \\
\hline 3.10 & Subcriticality & $K_{e f f}<0.95$ \\
\hline 3.13 & Handling features & $\begin{array}{l}\text { Provide grapple and canister with lifting } \\
\text { flange. Grapple must be remotely operable } \\
\text { within a right-circular cylindrical cavity with } \\
\text { diameter equal to that of the canistered waste } \\
\text { form. }\end{array}$ \\
\hline 4.0 & Quality assurance & $\begin{array}{l}\text { Provide quality assurance program complying } \\
\text { with } O G R^{6} / B-14 \text {. }\end{array}$ \\
\hline
\end{tabular}

${ }^{\circ}$ ANSI = American National Standards Institute.

BOGR = Office of Geologic Repositories.

Because of the relatively short half-life periods of strontium-90 $\left({ }^{90} \mathrm{Sr}\right)$ and cesium-137 ( $\left.{ }^{137} \mathrm{Cs}\right)(27.7 \mathrm{yr}$ and $30 \mathrm{yr}$, respectively), it may be possible to demonstrate that the actual radionuclide releases will be inconsequentially small by the end of the 1,000-yr repository containment period. Such an analysis has not been fully pursued and would be complicated by the following considerations:

1. Long-lived impurities such as cesium-135 ( $\left.{ }^{935} \mathrm{Cs}\right)$ might contain enough residual radioactivity at the end of the repository containment period to invalidate the concept.

2. Complete containment of the highly soluble materials cannot be ensured for the first $1,000 \mathrm{yr}$ because of the high reactivity between the cesium and strontium salts and the capsule and canister materials (see discussion of WAPS 3.9 in Section 3.2.3).

3. The current specification for borosilicate glass does not permit any computation of the aging of the waste form. Durability is to be evaluated at the time of production.

4. Preliminary assessments from the geologic repository project indicate that the comparatively high solubility of CsCl and the uncertain chemical behavior of $\mathrm{SrF}_{2}$ will preclude their direct use in the repository because of complications in the licensing process (Oversby 1990; Harrison-Giesler 1990). 


\subsubsection{Waste Acceptance Preliminary Specification 1.4: Chemical and Phase Stability (10 CFR 60.135[a][2])}

This specification is designed to document the thermal conditions under which the waste form will undergo significant chemical or physical changes. Although the specification is tailored specifically for borosilicate glasses, it is clear that a waste form that is not stable under expected storage or repository conditions will not be acceptable. Neither $\mathrm{CsCl}_{\text {nor }} \mathrm{SrF}_{2}$ is subject to decomposition within the temperature ranges expected for storage or repository disposal; however, impurities can lower the decomposition temperature into this range. It will be necessary to negotiate the waste form's chemical and phase stability requirements with the repository before adopting this disposal approach.

The thermal phenomena of interest for the waste form are phase transitions, such as solid phase changes and melting. Solid phase changes that increase the waste form volume could potentialiy cause a rupture of the capsule. Production of a liquid phase by melting could al so accelerate internal corrosion of the capsule. Strontium fluoride with sodium fluoride (NaF) impurities has a minimum melting temperature of $850^{\circ} \mathrm{C} \pm 5{ }^{\circ} \mathrm{C}$ (Fullam 1977) and has no known phase transformations below this temperature (Watrous and Chen 1978). Storage of $\mathrm{SrF}_{2}$ below $850^{\circ} \mathrm{C}$ should be adequate to avoid liquid phase volume expansion and the resulting capsule stresses. Cesium chloride with impurities has a solid phase transformation at $465{ }^{\circ} \mathrm{C}$ (Fullam 1971). The minimum melting point of $\mathrm{CsCl}$ with 5 wt\% $\mathrm{NaCl}$ and potassium chloride $(\mathrm{KCl})$ is $580{ }^{\circ} \mathrm{C}$ (Fullam 1971), although a CsCl-ferric chloride $\left(\mathrm{FeCl}_{3}\right)$ mixture can melt at a temperature as low as $270{ }^{\circ} \mathrm{C}$. Because the $\mathrm{CsCl}$ capsules are melt-cast, the voids produced on cooling should permit the volume expansion that accompanies the solid-to-liquid transformation to occur without stressing the capsule.

\subsubsection{Waste Acceptance Preliminary Specification 3.9: Chemical Compatibility (10 CFR 60.134[a][1])}

The WAPS's for borosilicate glass require that the contents of the canistered waste form shall not corrode the canister such that there will be an adverse effect on normal handling during storage, transportation, and repository operation. The extent of corrosiveness and chemical reactivity among the waste form, canister, and any filler materials must al so be documented, as well as corrosive chemical interactions, and any reaction products generated within the canistered waste forms.

The chemical compatibilities of $\mathrm{CsCl}$ and $\mathrm{SrF}_{2}$ with the capsule containment materials have been studied extensively (Fullam 1972, 1981; Bryan 1987), including the effects of impurities and daughter products. The principal impurities for $\mathrm{CsCl}$ are sodium chloride $(\mathrm{NaCl})$ and $\mathrm{KCl}$, while numerous metal fluorides, principally barium fluoride ( $\left.\mathrm{BaF}_{2}\right)$, calcium fluoride $\left(\mathrm{CaF}_{2}\right)$, and $\mathrm{NaF}$ are found with $\mathrm{SrF}_{2}$. Because ${ }^{137} \mathrm{Cs}_{2}$ decays to ${ }^{137} \mathrm{Ba}$, the $\mathrm{CSCl}$ decays to $\mathrm{BaCl}$, which is chemically unstable, with the reaction $2 \mathrm{BaCl} \rightarrow \mathrm{BaCl}_{2}+\mathrm{Ba}$. The ${ }^{90} \mathrm{Sr}$ decays to $90 \mathrm{Y}$, which further decays to ${ }^{90} \mathrm{Zr}$. As with $\mathrm{BaCl}, 2 r F_{2}$ is chemically unstable, with reaction $2 \mathrm{ZrF}_{2} \rightarrow \mathrm{ZrF}_{4}+\mathrm{Zr}$. 
Long-term strontium corrosion studies (Fullam 1981) found that chemical attack of the Hastelloy C-276 inner capsule containment material results primarily from impurities in the $\mathrm{SrF}_{2}$. Once the critical impurities are consumed by the corrosion reaction (up to $12,000 \mathrm{~h}$ ), the rate of chemical attack decreases to a low level. Fullam concludes that, for heat source applications, maintaining the temperature of the capsule wall below $800{ }^{\circ} \mathrm{C}$ would adequately contain the $\mathrm{SrF}_{2}$ for 10 to $20 \mathrm{yr}$. Because the reacting impurities are expected to be consumed by that time, additional corrosion is expected to be minimal.

Long-term cesium studies (Bryan 1987) examined $\mathrm{CsCl}$ capsules after extended storage at $350^{\circ} \mathrm{C}$ to $450^{\circ} \mathrm{C}$. Linear extrapolations of initial corrosion rates suggested capsule wall failure in 25 to $35 \mathrm{yr}$. Corrosion rates at lower temperatures appeared to be much slower. Moreover, because corrosion appears to result mostly from impurities, it is expected that the rate would decrease as the impurities are consumed. 
WHC-EP-0460

\subsection{EVALUATION OF HWVP PROCESSING CONSIDERATIONS}

This study focuses on five major issues concerning the incorporation of higher cesium, strontium, chloride, and fluoride levels into existing HWVP feedstreams: (1) the effect on glass composition and processability, (2) the effect on glass release properties, (3) the effects of increased canister curie and watt levels on meeting WAPSs and shipping requirements, (4) the effects on offgas volatility and treatment, and (5) the effect on vitrification equipment materials compatibility. Each of these issues is discussed in the following subsections.

For this study, it was assumed that the base case would be to blend all of the $\mathrm{CsCl}$ and $\mathrm{SrF}_{2}$ from the capsules with neutralized current acid waste (NCAW). The NCAW stream is the first Hanford Site waste stream to be processed in the HWVP. Therefore, the timing for coprocessing of the two streams will be critical. If scheduling prevents blending with NCAW, the capsule waste could be blended with complexant concentrate (CC) waste or processed as a separate feed stream. Blending was considered only for the NCAW and CC waste streams because these are the two waste streams defined as "high-level waste." Appendix B summarizes calculations and estimates of NCAW composition after blending and the curie and watt loadings in the resulting glass canisters. Appendix $C$ summarizes calculations and estimates of the $C C$ composition after blending and the curie and watt loadings in the resulting glass canisters. Section 4.1 discusses the processing of the capsule waste as a separate feed stream.

\subsection{GLASS COMPOSITION AND PROCESSABILITY}

Borosilicate glass has been selected as a waste form for nuclear waste immobilization because of its optimum combination of durability, processability, and acceptable waste loading characteristics. Failure of the glass to constrain the radionuclides would require failure of the glass structure itself. By definition, glass is an amorphous material forming a random structure. The glass structure has three main parts: (1) glass or network formers, primarily composed of oxides of silicon and boron, that provide the basic structure; (2) network modifiers, which include alkali metal and alkaline earth oxides and are used as fluxes to reduce the temperature required for processing; and (3) intermediates, such as aluminum oxide and other transition series oxides, which can take on the coordination of glass formers and play a role like the network formers. To a certain extent, the majority of elements in the periodic table can be accommodated in the glass structure. Therefore, the complex mixture that makes up defense high-level waste can be blended with the proper glass formers and any necessary intermediates and modifiers in the proper proportions to produce a glass waste form.

Limits have been established for volatile and nonvolatile oxides and elements in the reference glass for NCAW (WHC 1989). The weight percent limits for $\mathrm{Cl}^{-}$and $\mathrm{F}^{-}$are given in Table 4-1. The maximum $\mathrm{Cl}^{-}$limit has been set at the nominal value and does not indicate that the HWVP can only process waste at these $\mathrm{Cl}^{-}$concentration. Future evaluation is expected to result in increasing the maximum $\mathrm{Cl}^{-}$concentration. 
Table 4-1. Limits for Chlorine and Fluorine in the Glass Form.

\begin{tabular}{|c|c|c|}
\hline \multirow{2}{*}{ Constituent } & \multicolumn{2}{|c|}{ HWVP process limit (wt\%) } \\
\cline { 2 - 3 } & Nominal & Maximum \\
\hline $\mathrm{Cl}^{-}$ & 0.08 & 0.08 \\
\hline $\mathrm{F}^{-}$ & 0.3 & 1.73 \\
\hline
\end{tabular}

The HWVP Technical Data Package (TDP) (WHC 1989) has also set a 1.25 wt\% maximum for all fission products. This upper limit is considered somewhat arbitrary, because testing has not determined a maximum limit based on maintaining acceptable glass properties.

Cesium and strontium will enter the glass matrix as network modifiers. Much higher concentrations of $\mathrm{Cs}_{2} \mathrm{O}$ and SrO have been $\mathrm{placed}$ in borosilicate glass than are currently in NCAW. For example, the thermal and isotopic glass canisters produced for the Federal Republic of Germany (FRG) using the Pacific Northwest Laboratory (PNL) radioactive liquid-fed ceramic melter (RLFCM) contained $5.7 \mathrm{wt} \% \mathrm{Cs}_{2} \mathrm{O}$ and $1.9 \mathrm{wt} \%$ sro (Holton et a7. 1988). Acceptable glass properties (i.e., acceptable in terms of viscosity and electrical conductivity) were maintained by reducing the concentration of the alkali metals and alkaline earths that were in the reference glass composition (WV 205) after which the FRG glass was modeled. During the RLFCM campaigns, acceptable processing rates were achieved and volatility was determined to be typical of glasses containing low levels of cesium and strontium. Inspection of glass samples taken from the pour stream and views of the glass surface at the top of the canisters confirmed that secondary cesium or strontium phases had not formed.

The 1,349 cesium capsules have a total inventory of $2,875 \mathrm{~kg}$ of cesium. The $636 \mathrm{SrF}_{2}$ capsules have a total strontium inventory of $1,198 \mathrm{~kg}$. If distributed uniformly throughout the estimated 480 canisters of NCAW glass to be produced, the concentrations of $\mathrm{Cs}_{2} \mathrm{O}$ and $\mathrm{SrO}$ in the glass would increase to $0.53 \mathrm{wt} \%$ and $0.28 \mathrm{wt} \%$, respectively. These values are well within the processing envelope established by the production of FRG canisters cited above. Therefore, the cesium and strontium could be incorporated into the NCAW waste stream without impacting processing characteristics.

If evenly distributed throughout the currently estimated 650 canisters of $\mathrm{CC}$ waste, the concentrations of $\mathrm{Cs}_{2} \mathrm{O}$ and $\mathrm{SrO}$ in the glass would increase to 0.40 and $0.13 \mathrm{wt} \%$, respectively. Again, these values are well within the limits established by previous experience. Therefore, the cesium and strontium could be successfully incorporated into the $C C$ waste stream without impacting processing. Reconsideration of this approach would be necessary if the TRUEX process were employed for $C C$ waste pretreatment. However, more than a tenfold reduction in the number of canisters would have to occur as a result of using the TRUEX process before the empirically established limits would be approached. 
The behavior of fluorine in borosilicate glasses differs in many respects from the other halogens. The effective radius of fluorine is very close to that of oxygen. This permits fluorine to partially replace oxygen in the glass. The other halogens are larger and much less stable as components in the glass structure. Because of the ability to replace oxygen in the glass, fluorine has a higher solubility in the glass than the other halogens. Generally, most clear commercial glasses contain at most 0.6 wt\% fluorine compared to 0.1 wt\% chlorine (Volf 1984), in part because of the use of fluorine compounds as glass-fining agents. Both liquid and crystalline phase separation occurs above the solubility limit, causing opacity. The presence of elements such as aluminum and boron in the glass somewhat increases the solubility of fluorine in the glass. Work performed by Bates (1987) in which concentrations as high as 4.3 wt\% were tested demonstrated that a fluorine concentration of $1.73 \mathrm{wt \%}$ in $\mathrm{HW}-39$ glass was acceptable. Crystalline phase separation at 3.0 wt\% necessitated lowering the limit to the next lower concentration tested (i.e., 1.73 wt\%).

Previous testing at PNL has included feeds with chlorine concentrations up to 0.3 wt\% (Savannah River feeds), 0.35 wt\% (West Valley feeds), and at least 0.08 wt\% (HWVP feeds). Although halides can form molten metal salts that can accumulate on the glass surface, only minimal quantities of such salts have ever been observed. Chlorine and fluorine concentrations in NCAW glass will increase from reference levels of 0.075 and 0.3 wt\%, respectively, to 0.17 and $0.37 \mathrm{wt} \%$, respectively, with the incorporation of the capsule material. Chlorine and fluorine concentration in the $C C$ glass will increase from reference levels of 0.25 and $0.05 \mathrm{wt} \%$, respectively, to 0.35 and 0.12 wt\%, respectively, with the incorporation of the capsule material. Based on results from previous tests, processing conditions and glass characteristics will be acceptable if the cesium and strontium salts are blended with pretreated NCAW and/or CC waste and processed through HWVP.

Only a small increase in the number of canisters produced results from incorporating the capsule materials. If one assumes no change to the $25 \mathrm{wt} \%$ waste loading limit, a total of $5,359 \mathrm{~kg}$ of wastes will be vitrified, an amount equivalent to $21,436 \mathrm{~kg}$ of glass. This will result in the production of 13 additional canisters, irrespective of the waste $\operatorname{stream}(s)$ (i.e., NCAW and/or (C) to which the cesium and strontium are added.

Another option would be to vitrify the capsule waste in a separate HWVP campaign. This option might be necessary in the event of scheduling conflicts, or some other technical limitation that would prevent blending the capsule waste with planned HWVP feed streams. For this option, the CsCl and $\mathrm{SrF}_{2}$ would be dissolved or slurried in one of the HWVP tanks, blended with glass formers, and fed to the melter. Additional canisters would be produced, the number being determined by glass composition limits. Assuming the maximum concentrations of the four capsule constituents are the same as the values discussed earlier, the total number of canisters of glass produced would be dictated by one of the following cases:

- $2,875 \mathrm{~kg} \mathrm{Cs} / 5.3 \%$ Cs limit $=54,245 \mathrm{~kg}$ glass $=33$ canisters

- $1,198 \mathrm{~kg} \mathrm{Sr} / 1.6 \% \mathrm{Sr}$ limit $=74,875 \mathrm{~kg} \mathrm{glass}=45$ canisters 
- $767 \mathrm{~kg} \mathrm{Cl} / 0.35 \% \mathrm{Cl}$ limit $=219,142 \mathrm{~kg}$ glass $=133$ canisters

- $519 \mathrm{~kg} \mathrm{~F} / 1.73 \% \mathrm{~F}$ limit $=30,000 \mathrm{~kg}$ glass $=18$ canisters.

Chloride is shown above to be the limiting case, resulting in 133 canisters. Separation of the halides from the cesium and strontium would significantly reduce the total number of canisters to 45 .

In the year 2010 , the decay heat in these 133 canisters would be about $2,000 \mathrm{~W} / \mathrm{canister}$, which is higher than the nominal HWVP heat loadings (400 W/canister) but not technically prohibitive. At this power level the centerline temperature of the glass canister does not exceed the phase transition temperature for borosilicate glass. The cost of production and repository disposal for the 133 canisters, based on $\$ 500,000 /$ canister, is estimated to be $\$ 66.5$ million. For 45 canisters, the cost is estimated to be $\$ 22.5$ mil1ion.

\subsection{GLASS DURABILITY}

Specification 1.3 of the reference version of the WAP requires that the $\mathrm{glass}$ product leach at a rate of less than $1 \mathrm{~g} / \mathrm{m}^{2}-d$ based on measuring the fractional release of cesium, sodium, silicon, boron, and uranium in an MCC-1 test conducted during a 28-d period. An alternative test, such as the Product Consistency Test (PCT), may be used if the results can be related to the MCC-1 acceptance criterion. If the release of any of the five listed elements exceeds the $1 \mathrm{~g} / \mathrm{m}^{2}-d$ criterion, a more durable glass must be developed.

Because the leach rate is based on the amount of cesium lost divided by the fraction of cesium originally in the glass, the relative value should stay the same with the higher cesium-containing glasses. The reference glass composition, $H W-39-4$, has a leach rate for cesium of about $0.74 \mathrm{~g} / \mathrm{m}^{2}-\mathrm{d}$ (Goles and Nakaoka 1990). This rate is quite high and is almost $75 \%$ of the WAPS limit. Any significant increase in the cesium concentration should require leach testing of the candidate glass to determine the cesium leach rate.

A draft revision to Specification 1.3 of the WAPS proposes that production glass samples be tested exclusively by the PCT, and the results compared to PCT results for DWPF Environmental Assessment (EA) benchmark glass for releases of lithium, sodium, and boron. The change to the PCT was made to decrease analytical uncertainties and shorten the time required for radioactive testing. Reference to the EA glass was invoked with the intent of bounding the release rate of future glasses to, as a minimum, the performance of the glass in the EA. Unpublished data from the DWPF indicate that these changes are not restrictive.

\subsection{RADIATION THERMAL LOADING}

Calculations were completed to determine the impact of blending the capsule material with NCAW and CC waste (the calculations are summarized on page 3 of Appendixes $B$ and $C$ ). For NCAW, it is estimated that at the time the HWVP begins operating, the curie content would increase between $89 \%$ (maximum 
curie case) and $99 \%$ (nominal watt case) above the current reference cases. The watts per canister would increase between $82 \%$ (maximum watt case) and $181 \%$ (nominal curie case) above the current reference cases. As stated in Section 3.3, the year 2015 is the earliest time defense wastes will begin to be shipped to the repository.

As demonstrated in Figure $4-1$, as much as $50 \%$ of the radioactivity present in NCAW glass in the year 2000 will be gone by the time the canisters are shipped to the repository. The increase in watt loading will increase the centerline temperature of the canister. The WAPS state that the centerline temperature should remain below the glass transition temperature during interim storage and be at least $100^{\circ} \mathrm{C}$ below the glass transition temperature $\left(T_{g}=500^{\circ} \mathrm{C}\right)$ when the canisters are shipped to the repository. Figure 4-2 presents an estimate of the canister centerline temperature as a function of canister watt loading (Elmore 1986). It is apparent that the watt loading must increase by almost a factor of 5 above the maximum value of 1,524 W/ canister being considered here before the centerline temperature criterion is violated.

The facility shielding requirements also must be considered. Section 12 , Item 200 of the HWVP TDP addresses shielding requirements. As a conservative approach, the HWVP project staff have used estimated curie levels that are $260 \%$ above the maximum values used in the calculations reported in Appendix B. Therefore, the inclusion of the cesium and strontium salts in the NCAW feed should not require greater shielding requirements than what is currently planned.

\subsection{OFFGAS YOLATILITY AND TREATMENT}

Higher cesium volatility may be expected as a result of the increase in halide concentration (Goles and Andersen 1986). The increase in cesium concentration itself has not been shown to increase the rate of cesium loss from the melter (Goles and Andersen 1986). Goles and Andersen (1986) reported a minimum cesium decontamination factor $(D F)^{1}$ of 9.5 . This DF can be compared to the cesium DF of 14 for the HWVP design reference melter (Goles and Nakaoka 1990). These values can be placed into perspective by comparing them to the cesium DFs of 83 actually achieved during PSCM-23 (Goles and Nakaoka 1990) and 21 actually achieved during RLFCM operations with 5.7 wt\% $\mathrm{Cs}_{2} \mathrm{O}$ (Holton et al. 1988). It would be expected that actual ceramic melter testing would be conducted to develop offgas performance data. However, based on the data at hand, combining the NCAW and capsule salts should not have any severe impacts on the offgas treatment system.

Based on estimates made by Goles and Andersen (1987), the projected stack release of fluoride was $0.6 \%$ of the ambient air quality limit. Accounting for the increase in the HWVP production glass rate from $45 \mathrm{~kg} / \mathrm{h}$ to $100 \mathrm{~kg} / \mathrm{h}$ since the time of that study, and the added fluoride contributed from the $\mathrm{SrF}_{2}$, the

\footnotetext{
${ }^{1}$ Melter cesium DF is the ratio of the mass of cesium entering the melter to the mass of cesium escaping into the offgas treatment system. The percent retention in the glass $=(1-1 / D F)(100)$.
} 
WHC-EP-0460

Figure 4-1. Rate of Decay of Neutralized Current Acid Waste Canister Radionuclides.

Yoar

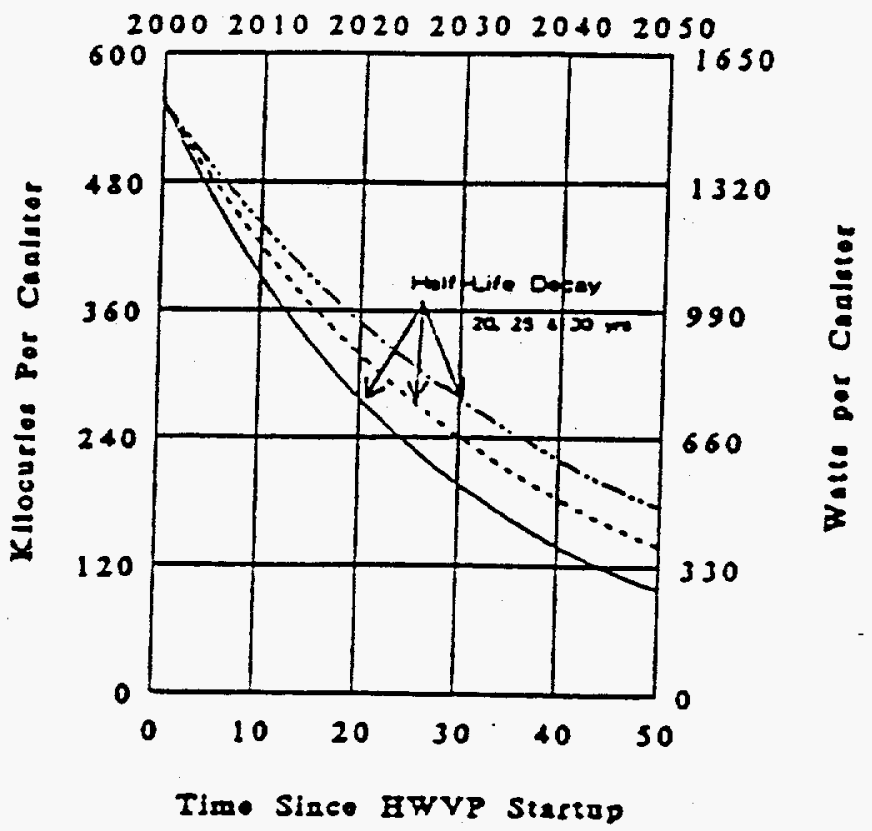


Figure 4-2. Effects of Canister Watt Loading on Canister Centerline Temperature.

HWYP CANISTER CENTERLINE TEMPERATURE Effect of Glass Heat Loading

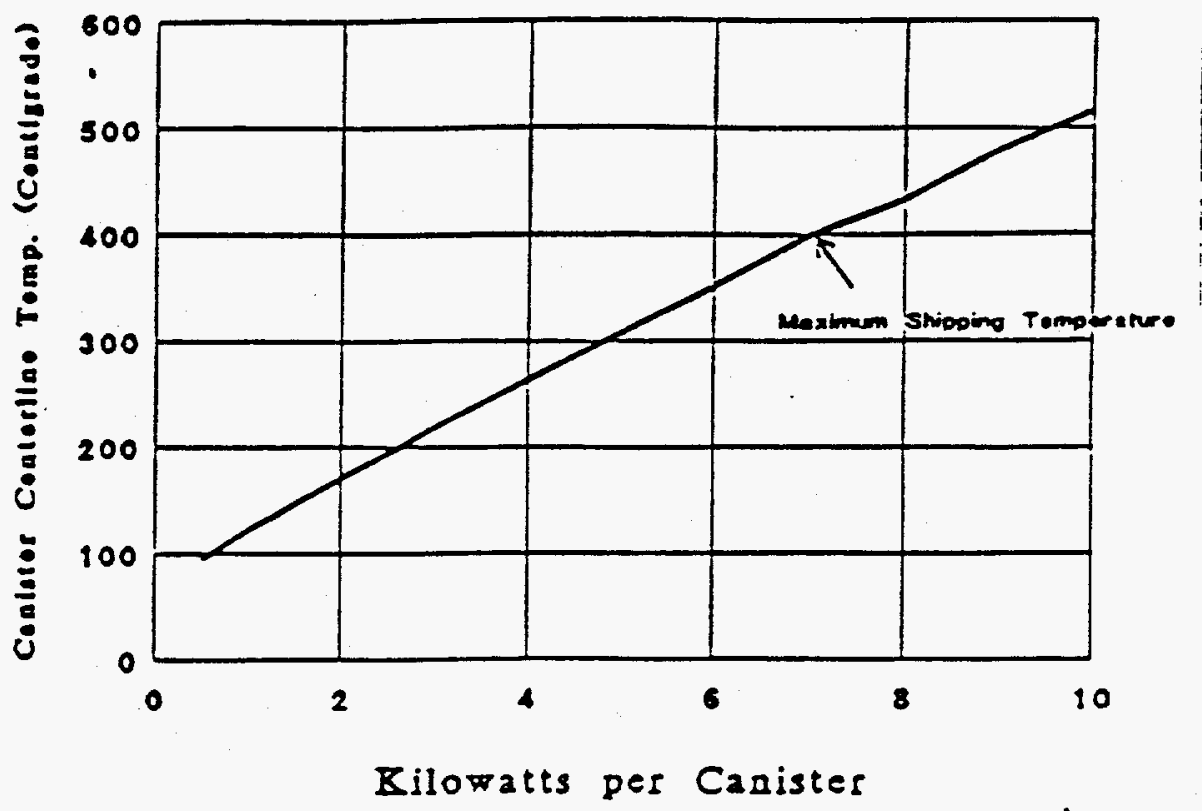


fluoride content in the offgas may increase by a factor of 3 . Increasing the stack release of fluoride by a factor of 3 would result in the stack releases being just $1.8 \%$ of the limit value of $0.5 \mathrm{\mu g} / \mathrm{m}^{3}$.

For cesium, the projected stack release was estimated to be $0.7 \%$ of the limit. If $\mathrm{CsCl}$ capsule waste is vitrified, the stack release could increase to about $5.5 \%$ of the 1 imit (assuming the same ratio of ${ }^{137} \mathrm{Cs}$ in the capsule and NCAW wastes). Goles and Andersen determined that expected strontium releases would be six orders of magnitude lower than the stack limits. Thus, increase in strontium as a result of capsule waste treatment would have no significant effect on the stack release projection. An air emission 1 imit has not been assigned for chioride; therefore, chloride release was not included in this evaluation.

\subsection{EQUIPMENT MATERIALS COMPATIBILITY}

New contaminants not presently in NCAW waste would not be introduced with the inclusion of the capsule salts. Melter DFs for chlorine and fluorine during PSCM-23 were 5 and 7.6, respectively, while HWVP design DFs are 2 and 5 , respectively (Goles and Nakaoka 1990). Fluorine would increase by about $25 \%$ in the melter feed stream, while chlorine would increase by almost $130 \%$. Impacts of higher anion concentrations on the in-cell equipment need to be evaluated. However, increases of this magnitude are not expected to increase expected corrosion rates of the equipment. Evaluations performed by Elmore and Jensen (1990) and information that they gathered during other tests for DOE indicated that applicable slurry studies have been done with chioride and fluoride concentrations up to $20,000 \mathrm{ppm}$ and $2,300 \mathrm{ppm}$, respectively. Offgas condensate solutions have also been tested with up to $80,000 \mathrm{ppm}$ and $9,000 \mathrm{ppm}$ chloride and fluoride, respectively. Depending on $\mathrm{pH}$, several alloys were identified as candidate materials for use in high halide environments. The a lloy Hastelloy C-22 exhibited the lowest corrosion rates, generally less than $5 \mathrm{mil} / \mathrm{yr}$. If the proper materials are used for the in-cell equipment, the HWVP could accomodate the halides from the cesium and strontium capsules.

Processing conditions and glass characteristics will be acceptable if the cesium and strontium salts (cesium, strontium, chlorine, and fluorine) are blended with pretreated NCAW and/or CC waste and processed through HWVP. Leach testing of glasses produced using NCAW and CC waste containing cesium and strontium salts would be required to confirm acceptable glass durability. The canister watt loading and centerline temperature will increase as a result of adding the capsule waste, but at the time of shipment to the geologic repository, the canisters will satisfy the WAPS. Ceramic melter testing would be required to obtain offgas performance data; however, it is estimated that the HWVP offgas treatment can handle the increased cesium, strontium, chlorine, and fluorine. The increases in halide concentrations should not increase the expected corrosion rates for HWVP equipment. 
WHC-EP-0460

\subsection{PROCESS DESCRIPTIONS FOR HALIDE SEPARATION}

This section describes flowsheets for separating the chloride and fluoride from the capsule waste.

\subsection{BACKGROUND}

The double-shell tanks for the HWVP feedstreams are designed to accept contents in a pumpable form (i.e., slurry) only. Therefore, the direct blending of $\mathrm{CsCl}$ and $\mathrm{SrF}_{2}$ with the HWVP feedstreams in the holding tanks is only possible if the salts are in liquid form. Blending of $\mathrm{CsCl}$ in liquid form is relatively simple because $\mathrm{CSCl}$ has a very high solubility in water. On the other hand, $\mathrm{SrF}_{2}$ is almost insoluble in water and, therefore, the salt has to be crushed into powder and then mixed with enough water to form a slurry before transfer to tanks for the HWVP feedstreams. When halides cannot be added to the HWVP feedstreams, separation of chloride and fluoride from cesium and strontium will be required.

\subsection{SEPARATION OF CHLORIDE FROM CESIUH CHLORIDE}

Cesium can be separated from chloride by chemical reaction or ion exchange. One chemical reaction method is the separation of $\mathrm{Cs}^{+}$from $\mathrm{Cl}^{-}$by precipitation of the chloride using silver nitrate $\left(\mathrm{AgNO}_{3}\right)$. This reaction exploits solubility differences of the reaction products to achieve the final separations. Dissolving $\mathrm{CsCl}$ in water and mixing with a solution of $\mathrm{AgNO}_{3}$ results in almost complete removal of the chloride ion as solid silver chloride $(\mathrm{AgCl})$. In using ion exchange, dissolved $\mathrm{CsCl}$ is fed to a cation exchange column where cesium is held up and an electrolyte such as hydrogen chloride ( $\mathrm{HCl}$ ) is discharged. The cesium on the column could then be eluted using nitric acid $\left(\mathrm{HNO}_{3}\right)$.

\subsubsection{Ion Exchange}

Ion exchange material for cesium-bearing solutions has been demonstrated for West Valley supernatant (Bray et al. 1984) and also was produced at $B$ Plant to provide PNL with cesium for production of radioactive glass sources. Duolite Cs-100 resin was used for the work at B Plant and is assumed to be the material used for this study. The material balance is shown in Figure 5-1. This balance is based on an exchange capacity of 1.4 equivalents/L, a bed service life of 10 cycles or regenerations, and an elution volume of 5 column volumes. The elution agent is assumed to be $1 \mathrm{M} \mathrm{HNO}_{3}$. The process would involve dissolving $\mathrm{CsCl}$ in water and then feeding the solution to the top of a column. The $\mathrm{Hcl}$ would be discharged out the bottom as $\mathrm{CS}^{+}$is exchanged for $\mathrm{H}^{+}$. When the column is loaded, it could then be regenerated with $1 \mathrm{M} \mathrm{HNO}_{3}$, thus discharging cesium nitrate $\left(\mathrm{CSNO}_{3}\right)$ and excess acid. This eluted stream would be blended with the HWVP feed. The $\mathrm{HCl}$ stream that is produced could be neutralized and grouted. The spent resins could also be solidified in grout for disposal. 


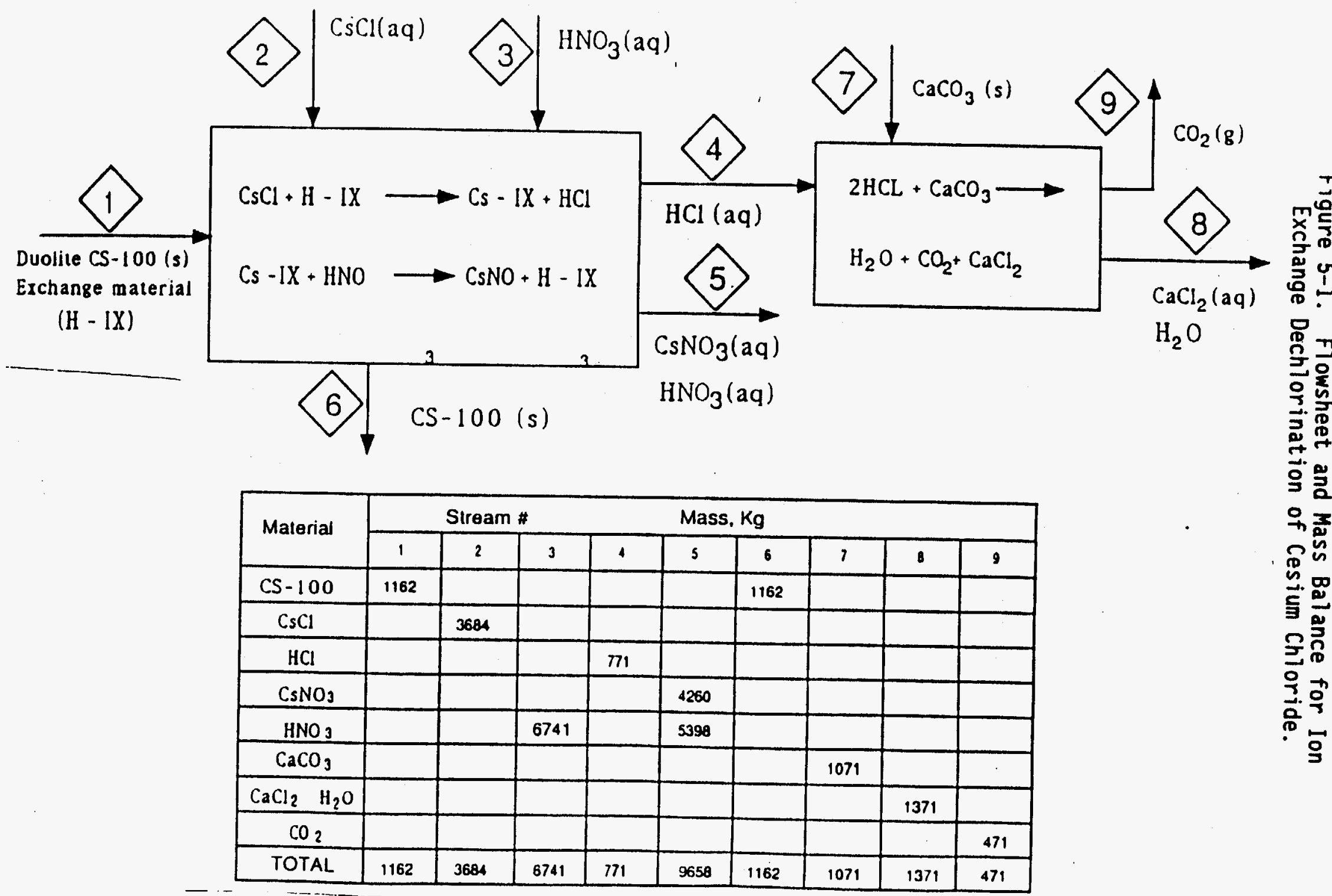




\subsubsection{Reaction with Silver Nitrate}

The flowsheet and mass balance for $\mathrm{AgNO}_{3}$ treatment are given in Figure 5-2. To convert the $3,642-\mathrm{kg}$ inventory of $\mathrm{CsCl}$ to $\mathrm{CsNO}_{3}$, a quantity of $3,675 \mathrm{~kg}$ of $\mathrm{AgNO}_{3}$ is required, which results in the production of $4,216 \mathrm{~kg}$ of $\mathrm{CsNO}_{3}$. Initially, $\mathrm{AgNO}_{3}$ and $\mathrm{CsCl}$ are prepared as aqueous solutions. The final solution volume can be adjusted according to the solubility limit of $\mathrm{CsNO}_{3}$. At $25^{\circ} \mathrm{C}$, the solubility is about $1.7 \mathrm{M}$, and a final solution volume of $13,000 \mathrm{~L}$ is required to ensure solubility of the $\mathrm{CsNO}_{3}$. This volume could be reduced significantly by operating at higher temperatures because the solubility of $\mathrm{CsNO}_{3}$ increases greatly with temperature. The solubility of $\mathrm{AgCl}$ is so low that an increase in temperature results in very little additional chloride ion in the solution. Equilibrium calculations show that at $25^{\circ} \mathrm{C}$, about $7 \mathrm{~g}$ of chloride ion is in 16,000 L of saturated $\mathrm{AgCl}$ solution.

The $\mathrm{AgCl}$ is separated from the $\mathrm{CsNO}_{3}$ solution and processed as solid waste. The $\mathrm{CsNO}_{3}$ solution is blended with the HWVP feedstreams for further processing into glass.

\subsection{SEPARATION OF FLUORIDE FROM STRONTIUM FLUORIDE}

Strontium can be separated from fluoride by chemical reactions. The SrF is converted to strontium sulfate $\left(\mathrm{SrSO}_{4}\right)$ by reaction with sulfuric acid $\left(\mathrm{H}_{2} \mathrm{SO}_{4}\right)$. The process is analogous to manufacture of hydrofluoric acid by conversion of fluorite $\left(\mathrm{CaF}_{2}\right)$. Because sulfate is undesirable in melter feed, it can be removed by metathesis of $\mathrm{SrSO}_{4}$ with sodium carbonate $\left(\mathrm{Na}_{2} \mathrm{CO}_{3}\right)$. The resulting strontium carbonate $\left(\mathrm{SrCO}_{3}\right)$ is insoluble and can be dissolved to form strontium nitrate $\mathrm{Sr}\left(\mathrm{NO}_{3}\right)_{2}$ by treatment with $\mathrm{HNO}_{3}$.

\subsubsection{Acid Decomposition of Strontium Fluoride}

The yield on the acid decomposition was taken to be the same as that for $\mathrm{CaF}_{2}$ as given in the literature. The formula for the acid decomposition reaction is:

$$
\begin{aligned}
\mathrm{SrF}_{2}+\mathrm{H}_{2} \mathrm{SO}_{4}=\mathrm{SrSO}_{4}(\mathrm{~s})+2 \mathrm{HF}(\mathrm{g}) ; \Delta H^{\circ} & =8.3 \mathrm{kCal} / \mathrm{mol} \\
\Delta G^{\circ} & =-7.8 \mathrm{kcal} / \mathrm{mol}
\end{aligned}
$$

The above reaction is analogous to the acid decomposition of $\mathrm{CaF}_{2}$ (fluorite), which has been used industrially for the production of HF. It is assumed here that $\mathrm{SrF}_{2}$ can be decomposed by the same process. Simons (1950) indicates that all alkaline earth fluorides undergo acid decomposition, and thermodynamic calculations from standard heats of formation show the reaction of $\mathrm{SrF}_{2}$ to be more favorable than $\mathrm{CaF}_{2}$. Therefore, it could be expected that acid decomposition is feasible. 
Figure 5-2. Flowsheet and Mass Balance for the Removal of Chloride Ion from Cesium Chloride Solution by Precipitation with Silver Nitrate.

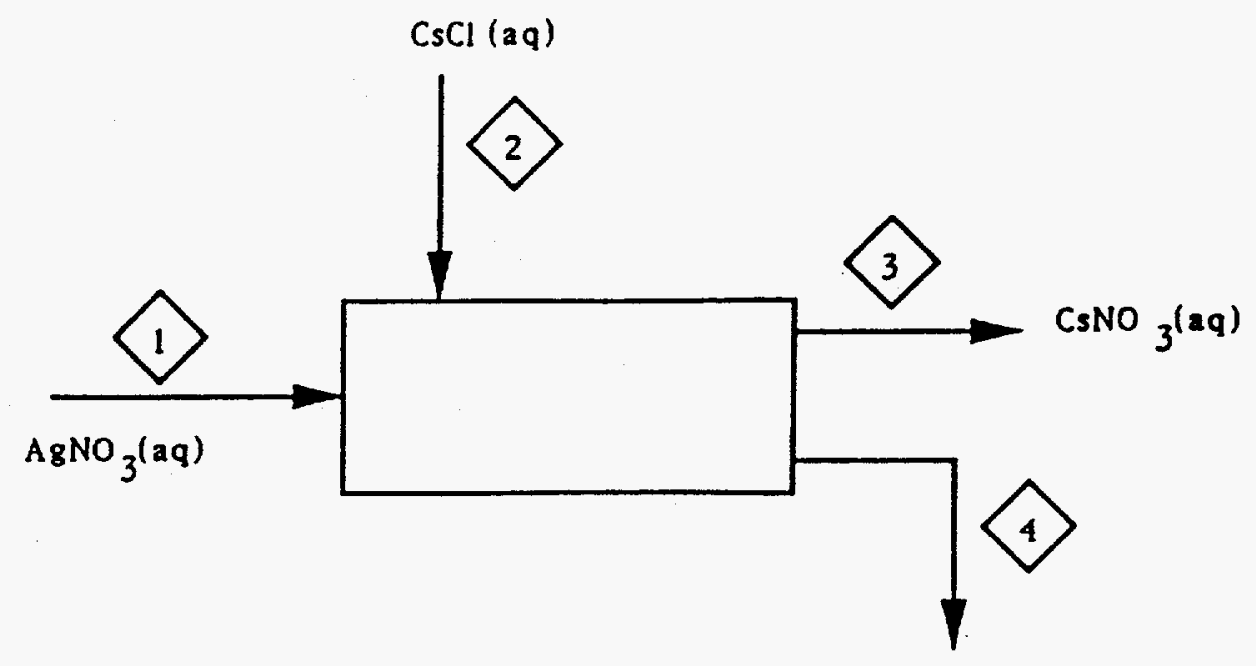

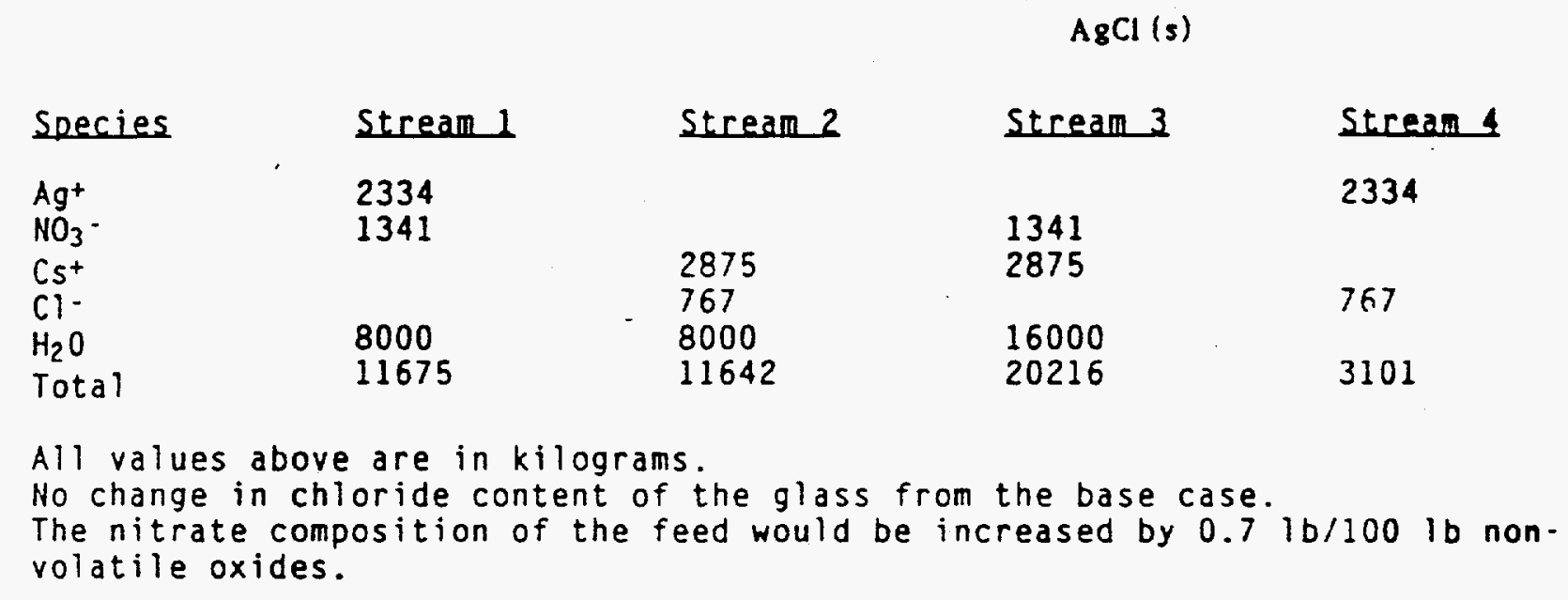


The flowsheet and mass balance for this acid decomposition are given in Figure 5-3 and Table 5-1, respectively. According to Table 5-1, about $1,493 \mathrm{~kg}$ of $\mathrm{H}_{2} \mathrm{SO}_{4}$ is required to react with a total inventory of $1,717 \mathrm{~kg}$ of $\mathrm{SrF}_{2}$, resulting in the production of about $2,393 \mathrm{~kg}$ of $\mathrm{SrSO}_{4}$. The process could be carried out either batchwise or continuously. The continuous process as described by Ryss (1956) is as follows: powdered $\mathrm{SrF}_{2}$ is mixed with $\mathrm{H}_{2} \mathrm{SO}_{4}$ in a mechanical mixing device. Over a period of 1 to $2 h$, the mixture passes through an externally heated revolving furnace at a temperature of $100{ }^{\circ} \mathrm{C}$ to $130{ }^{\circ} \mathrm{C}$. The HF is driven off as a gas and $\mathrm{SrSO}_{4}$ containing $2 \%$ to $3 \% \mathrm{SrF}_{2}$ and $7 \%$ to $8 \% \mathrm{H}_{2} \mathrm{SO}_{4}$ remains. At these low temperatures, very little $\mathrm{H}_{2} \mathrm{SO}_{4}$ contaminates the HF gas stream. If this contamination is not important in this process, then higher temperatures might accelerate the reaction. Further treatment by metathesis with $\mathrm{Na}_{2} \mathrm{CO}_{3}$, described below, could remove the sulfate, if necessary.

\subsubsection{Metathesis of Strontium Sulfate to Strontium Carbonate}

Without removal of the sulfate, the weight percent sulfate in NCAW glass is estimated to be 0.35 . The maximum limit for $\mathrm{SO}_{4}$ is 0.50 wt\%. The direct addition of $\mathrm{SrSO}_{4}$ to NCAW increases the concentration of sulfate in NCAW glass close to the specified sulfate limit for the glass; therefore, the solid $\mathrm{SrSO}_{4}$ can be converted to $\mathrm{SrCO}_{3}$ by treatment with aqueous $\mathrm{Na}_{2} \mathrm{CO}_{3}$ to el iminate this problem. Treatment of $\mathrm{SrSO}_{4}$ with $\mathrm{Na}_{2} \mathrm{CO}_{3}$ will result in the metathesis of $\mathrm{SrSO}_{4}$ into $\mathrm{SrCO}_{3}$ (both insoluble) and the sulfate will remain in solution as sodium sulfate $\left(\mathrm{Na}_{2} \mathrm{SO}_{4}\right)$ per the reaction:

$$
\mathrm{SrSO}_{4}(\mathrm{~s})+\mathrm{Na}_{2} \mathrm{CO}_{3}=\mathrm{SrCO}_{3}(\mathrm{~s})+\mathrm{Na}_{2} \mathrm{SO}_{4} \mathrm{~K}=250
$$

The equilibrium constant, $K$, shows this reaction to be quite favorable. If this reaction continues to completion, all the sulfate would be removed in the supernatant. The resulting carbonate has little effect on the total $\mathrm{CO}_{3}$ in the HWVP feed, increasing the value from 17 to $17.4 \mathrm{~kg} / 100 \mathrm{~kg}$ of nonvolatile oxides in the reference case. This reaction can be effective in reducing the amount of $\mathrm{SO}_{4}$ in the treated capsule waste.

The flowsheet and mass balance for this metathesis are given in Figure 5-4 and Table 5-2, respectively. The metathesis of $\mathrm{SrSO}_{4}$ generates a 1 iquid stream consisting of $2,161 \mathrm{~kg}$ of $\mathrm{Na}_{2} \mathrm{SO}_{4}, 136 \mathrm{~kg}$ of $\mathrm{H}_{2} \mathrm{CO}_{3}$, and unreacted $\mathrm{Na}_{2} \mathrm{CO}_{3}$ and $\mathrm{H}_{2} \mathrm{SO}_{4}$. The 1 iquid stream is processed and packaged as waste. The solid $\mathrm{SrCO}_{3}$ Can be transferred as a slurry for blending with NCAW.

\subsubsection{Dissolution of Strontium Carbonate in Nitric Acid}

Because slurry transfers may lead to plugging of transfer lines, thereby affecting the processing schedule, the $\mathrm{SrCO}_{3}$ can be converted to $\mathrm{Sr}\left(\mathrm{NO}_{3}\right)_{2}$ by reacting the $\mathrm{SrCO}_{3}$ with $\mathrm{HNO}_{3}$ as follows:

$$
\mathrm{SrCO}_{3}(\mathrm{~s})+2 \mathrm{HNO}_{3}=\mathrm{Sr}\left(\mathrm{NO}_{3}\right)_{2}+\mathrm{H}_{2} \mathrm{O}+\mathrm{CO}_{2}(\mathrm{~g})
$$


WHC-EP-0460

Figure 5-3. Flowsheet for the Acid Decomposition of Strontium Fluoride.

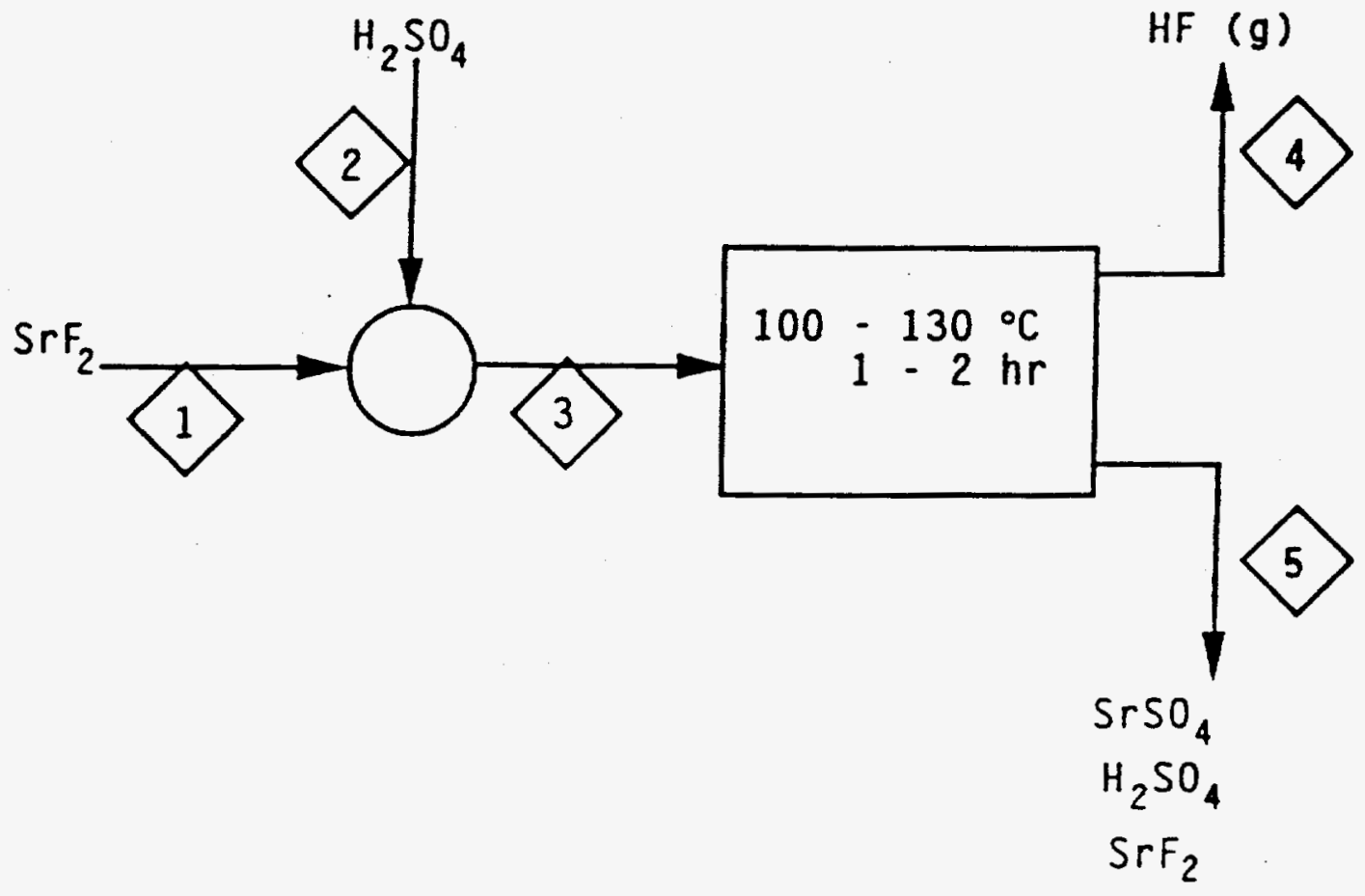

to be blended with NCAW waste or

further processed to $\mathrm{SrCO}_{3}$ 
Table 5-1. Mass Balance for the Acid Decomposition of Strontium Fluoride.

\begin{tabular}{|l|c|c|c|c|c|}
\hline & \multicolumn{5}{|c|}{ Stream number (kg) } \\
\cline { 2 - 6 } & 1 & 2 & 3 & 4 & 5 \\
\hline $\mathrm{SrF}_{2}$ & 1,717 & 0 & 1,717 & 0 & 80.6 \\
$\mathrm{H}_{2} \mathrm{SO}_{4}$ & 0 & $1,492.6$ & $1,492.6$ & 0 & 215.1 \\
$\mathrm{HF}$ & 0 & 0 & 0 & 521.3 & 0 \\
$\mathrm{SrSO}_{4}$ & 0 & 0 & 0 & 0 & $2,392.6$ \\
\hline Total & 1,717 & $1,492.6$ & $3,209.6$ & 521.3 & $2,688.3$ \\
\hline
\end{tabular}

Glass compositions

Quantity of fluorine after acid decomposition

$24 \mathrm{~kg}$

Quantity of fluorine in NCAW glass with treated capsules

$2,400 \mathrm{~kg}$ added

wt\% fluorine in NCAW glass with treated capsules added

0.303

wt\% fluorine in reference case

0.3

Quantity of $\mathrm{SO}_{3}$ in NCAW glass

$1,287 \mathrm{~kg}$

Quantity of $\mathrm{SO}_{3}$ after acid decomposition

$1,462 \mathrm{~kg}$

Quantity of $\mathrm{SO}_{3}$ in NCAW glass with treated capsules added

$2,749 \mathrm{~kg}$

wt\% of $\mathrm{SO}_{3}$ in NCAW glass with treated capsules added

0.35

wt\% $\mathrm{SO}_{3}$ in reference case

0.16 
Figure 5-4. Flowsheet for the Metathesis of Strontium Sulfate to Strontium Carbonate.

$\mathrm{SrSO}_{4}(\mathrm{~s})$

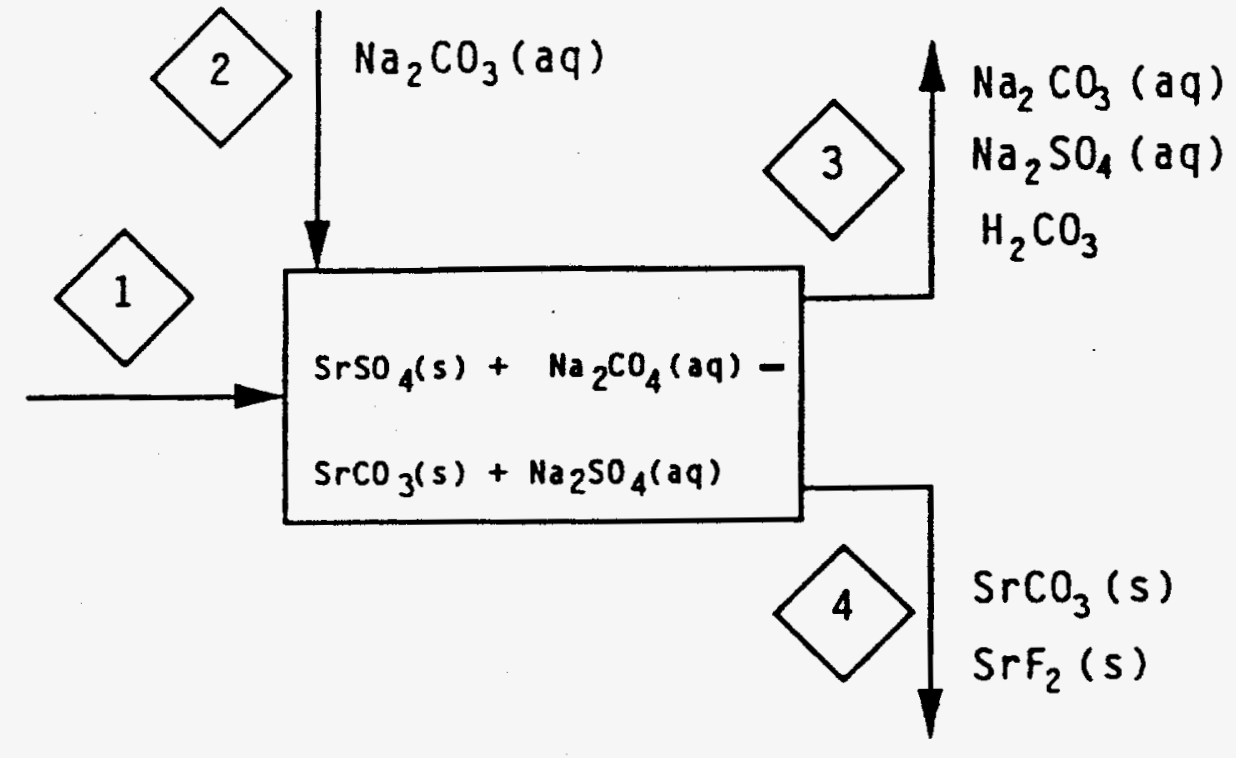


Table 5-2. Mass Balance for the Metathesis of Strontium Sulfate to Strontium Carbonate. ${ }^{a, b}$

\begin{tabular}{|l|r|r|r|r|}
\hline & \multicolumn{4}{|c|}{ Stream number (kg) } \\
\cline { 2 - 5 } & 1 & 2 & 3 & \multicolumn{1}{c|}{} \\
\hline $\mathrm{SrSO}_{4}$ & 2,393 & 0 & 0 & 0 \\
\hline $\mathrm{SrCO}_{3}$ & 0 & 0 & 0 & 1,923 \\
\hline $\mathrm{SrF}_{2}$ & 81 & 0 & 0 & 81 \\
\hline $\mathrm{Na}_{2} \mathrm{CO}_{3}$ & 0 & 2,120 & 507 & 0 \\
\hline $\mathrm{Na}_{2} \mathrm{SO}_{4}$ & 0 & 0 & 2,161 & 0 \\
\hline $\mathrm{H}_{2} \mathrm{CO}_{3}$ & 0 & 0 & 136 & 0 \\
\hline $\mathrm{H}_{2} \mathrm{SO}_{4}$ & 215 & 0 & 0 & 0 \\
\hline Total $_{2}$ & 2,688 & 2,120 & 2,804 & 2,004 \\
\hline
\end{tabular}

Glass composition changes: fluorine is unchanged from the acid decomposition case; $\mathrm{SO}_{3}$ is unchanged from the reference case.

${ }^{b}$ Feed composition changes:

$\mathrm{CO}_{3}$ in feed $(\mathrm{kg} / 100 \mathrm{~kg}$ nonvolatile oxides)

$17 \mathrm{~kg}$ Quantity of nonvolatile waste oxides in glass

Total quantity of $\mathrm{CO}_{3}$ (reference case) Quantity of $\mathrm{CO}_{3}$ in metathesized waste Total $\mathrm{CO}_{3}$ in feed with capsules added $\mathrm{CO}_{3}$ in feed with capsules added $(\mathrm{kg} / 100 \mathrm{~kg}$ nonvolatile oxides) $198,000 \mathrm{~kg}$ $33,660 \mathrm{~kg}$ $782 \mathrm{~kg}$ $34,442 \mathrm{~kg}$ $17.4 \mathrm{~kg}$

This will keep strontium in solution and ensure a successful and timely transfer of radioactive strontium for blending with NCAW. Equilibrium calculations show that in a $1 \mathrm{M}$ acid solution, the solubility of $\mathrm{SrCO}_{3}$ is about $0.5 \underline{M}(0.5 M$ in a $1 M$ acid solution).

The amount of $1 \mathrm{M} \mathrm{HNO}_{3}$ solution required to completely dissolve the $13 \mathrm{kmol}$ of $\mathrm{SrCO}_{3}$ is $26,000 \mathrm{~L}$. 
WHC-EP-0460

This page intentionally left blank. 


\subsection{EVALUATION OF FACILITIES AND EQUIPMENT}

The evaluation of facilities and equipment for processing the capsules through HWVP are detailed in this section. The section also identifies the required modifications to the facilities and equipment.

The removal of $\mathrm{CsCl}_{\text {and }} \mathrm{SrF}_{2}$ salts from the capsules and processing of the salts can be performed at either WESF or HWVP. If WESF is used for these operations, the processed liquids will be pumped to B Plant for blending with the waste feedstreams, and then to the double-shell tank 241-AY-102 (referred to as tank 102-AY) before finally being vitrified at the HWVP. However, if HWVP. is used for the capsule processing operations, the processed capsule waste can be blended directly with the waste feedstreams in the slurry receipt and adjustment tank (SRAT) at the HWVP, thereby bypassing the B Plant, tank 102-AY, and the receipt and 1 ag storage tank (RLST).

One decided advantage of processing the capsules directly in the HWV is in lessening the probability of a tank "bump" in tank 102-AY. A "bump" is caused when self-heating results in accumulation and subsequent release of gas. If the wastes going into tank 102-AY are to be concentrated before their transfer to HWVP for processing into glass, tank 102-AY might experience a tank bump. This problem will be exacerbated if the capsules containing cesium and strontium have to be processed through the 241-AY and -AZ Tank Farms. The cesium will be contained in the supernatant, but the strontium will settle to the tank bottom with the sludge. The presence of strontium in the sludge increases the self-heating of the sludge and will, therefore, increase the probability of a tank bump. Thus, the potential for a tank bump in tank 102-AY must be investigated before routing the capsule waste through the 241-AY and -AZ Tank Farms to the HWVP.

Processing the capsules directly at the HWVP will also bypass the RLST. The proposed construction material for this tank is AISI 316 . The waste composition in this tank is carefully controlled to avoid chloride stress corrosion cracking. The tightly controlled composition specification for this alloy sets limits on the chloride concentration of the wastes that will be treated by the tank. Presently, the liquid heel that remains in tank 102-AY is presumed to contain a high chloride concentration, which may be reduced to acceptable levels by mixing with wastes containing low chloride concentrations. However, blending the capsule waste with NCAW and/or CC waste may not reduce the chloride concentration of the waste feedstream to levels that are low enough to preserve the integrity of RLST.

The WESF will be used to perform TRUEX pilot-plant operations (under project $W-153$ ) and the HWVP bench-scale melter test simultaneously. Therefore, performing the capsule processing operations directly at the HWVP (with some modifications to the current HWVP design) will avoid any conflict with the two planned projects.

The following sections give the details for disassembly and processing of capsules at WESF. It should be noted, however, that the same process details also apply if operations are carried out in the HWVP. (See Section 6.3 for the modifications required to HWVP.) 
WHC-EP-0460

\subsection{BLEND CESIUM CHLORIDE AND STRONTIUH FLUORIDE DIRECTLY WITH NEUTRALIZED CURRENT ACID MASTE AND/OR CONPLEXANT CONCENTRATE HASTE}

The removal of $\mathrm{CSCl}_{\text {and }} \mathrm{SrF}_{2}$ salts from the capsules can be performed at WESF. The WESF building contains seven hot cells ( $A, B, C, D / E, F$, and $G$ ). The A Cell was previousiy used for solid waste loadout. The cell contains the equipment required for handling high-level solid waste from the remaining process cells. The portion of $A$ Cell that is adjacent to B Cell contains a stainless steel hood for receiving the contaminated solid waste and a transfer drawer that is accessible from the service gallery. Both B Cell and C. Cell were used for $S_{F} F_{2}$ processing. The D/E Cell is a double cell that was used for $\mathrm{CSCl}$ processing. The $\mathrm{F}$ Cell was previously used for decontamination of the inner capsules and subsequent welding and helium leak testing of the outer capsules. All of the operations are performed remotely with manipulators by operators positioned behind the lead glass windows of each cell. The G Cell was primarily used for placement of the outer capsules onto the inner capsules. Pass-throughs are located between adjoining cells for passage of equipment and solid waste. The WESF floor plan is discussed in more detail el sewhere (Sewe11 1986).

This option can be carried out in either $B$ and $C$ cells or the $D / E$ Cell of the WESF for both $\mathrm{CsCl}$ and $\mathrm{SrF}_{2}$ capsules.

\subsubsection{Dismantling of Cesium Chloride Capsules}

The WESF was previously used to dismantle $46 \mathrm{CsCl}$ capsules from the WESF pool cells and two CsCl capsules from Sandia Laboratory and to process CsCl for transfer to B Plant and ultimate transfer to PNL as $\mathrm{CSNO}_{3}$ solution in support of PNL's fabrication of isotopic heat sources for shipment to the FRG.

The WESF crew modified an existing pipe cutter to cut through the stainless steel outer capsule. The operations were performed in G Cell. This activity reduced the actual time of cutting and significantly reduced the amount of in-cell solid waste that would have been generated. Because of the very low smearable contamination, the cut up outer capsules were sent to lowlevel waste burial grounds. After the outer capsules were removed in $G$ Cell by cutting off the welded end caps, the inner capsules were transferred to the $D / E$ Cell and cut into three pieces using a chopsaw. The cut pieces were dumped into 5-gal-capacity buckets of water. This operation dissolved the $\mathrm{CsCl}$, leaving the inner capsule material unaffected. The stainless steel inner capsule materials were packaged in $0.21-\mathrm{m}^{3}(55-\mathrm{gal})$ drums and transported to the B Plant canyon. The drums with the capsule materials were stored at the B Plant canyon unt il there was enough contaminated equipment for disposal. The drums were then loaded into the drag-off boxes along with the equipment and buried in the 218-E-10 burial grounds in the 200 East Area. The water containing the dissolved $\mathrm{CsCl}$ was dumped into the sump of $\mathrm{D} / \mathrm{E} \mathrm{Cell}$, which used steam jets to pump the $\mathrm{CsCl}$ solution to $\mathrm{B}$ Plant for further processing.

The same procedure can be used again, although new chopsaws need to be assembled in-plant or procured from an outside vendor. The volume of water 
needed to process all $1,349 \mathrm{CsCl}$ capsules is conservatively estimated to be approximately $.4 .54 \mathrm{~m}^{3}(1,200 \mathrm{gal})$, resulting in approximately $5.68 \mathrm{~m}^{3}$ $(1,500 \mathrm{gal})$ of the processed solution for transfer to B Plant.

\subsubsection{Dismantling of Strontium Fluoride Capsules}

The method for cutting $\mathrm{CsCl}$ capsules with chopsaws at WESF has been demonstrated before. Although the same method can be used to cut the SrF

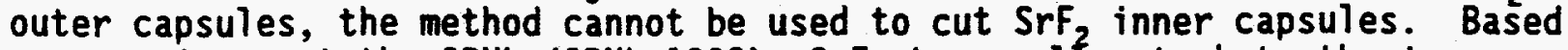
on experience at the ORNL (ORNL 1988), $\mathrm{SrF}_{2}$ is usualfy stuck to the inner Hastelloy capsule wall. The ORNL routinely made two longitudinal cuts 180 degrees apart on the Hastelloy capsule using a saw with a $0.13-m$ (5-in.)

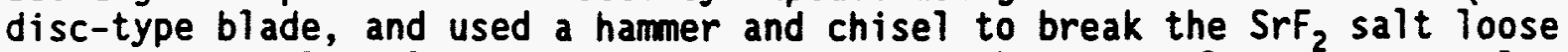
from the capsule walls. This operation broke the $\mathrm{SrF}_{2}$ salt into several pieces. Using this procedure, ORNL was able to process about six capsules in three 8-h shifts. The procedure, therefore, must be modified to include these steps. The chopsaws also require modification to make the longitudinal cuts. The solid waste (inner and outer capsule materials) generated can be disposed of in a manner similar to that of $\mathrm{CsCl}$ capsules, as described above.

Once the $\mathrm{SrF}_{2}$ salt is separated from the capsule into several pieces, the pieces can be transferred into a jaw crusher to crush $\mathrm{SrF}_{2}$ salt into particles $<300 \mu \mathrm{m}$ (number 50 sieve) size. Particles $>300 \mu \mathrm{m}$ (number 50 sieve) size can be recycled through the jaw crusher until the entire batch of capsules is crushed to $<300 \mu \mathrm{m}$ (number 50 sieve) size particles. Jaw crushers are available commercially for remote operations in a hot cell. The SrF powder can then be transferred to B Plant as a slurry in water, because $S_{r F}^{2}$ has negligible solubility in water.

The slurry transfer is expected to be possible only if the solids content is less than 4 vol\%. This limit is imposed to eliminate plugging of the transfer lines. Therefore, the volume of water used for transfer should be about 25 times as much as that of the solids--approximately $19.49 \mathrm{~m}^{3}$ $(5,150 \mathrm{gal})$ of water for processing all 636 capsules.

Because of limited space availabjlity in the WESF hot cells, tanks with capacity of no more than about $0.38 \mathrm{~m}^{3}$ (100 gal) can be accommodated. Therefore, for the $S_{r F}$ slurry processing, a $0.38-\mathrm{m}^{3}$ (100-gal) holding tank can be procured and the process of dismantling the capsules, crushing, mixing with water, and pumping into a holding tank can be made into a batch operation. The size of each batch can be fixed at 9 capsules, resulting in a total of 71 batches for processing all of the $636 \mathrm{SrF}_{2}$ capsules. Because the sump and the steam jets cannot be used to transfer the SrF 2 slurry, unlike the $\mathrm{CsCl}$ case, a vortex pump will be used to pump the slurry to B Plant. Before

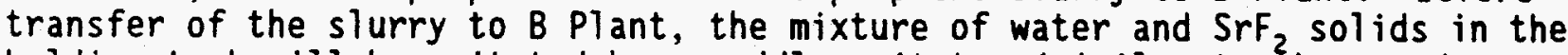
holding tank will be agitated by a paddle agitator (similar to the one in use at $B$ Plant) to keep the $\mathrm{SrF}_{2}$ solids from settling.

One primary cause for concern in transferring the slurry is the possibility that the $0.025-m$ ( $1-i n$.) transfer lines from WESF to B Plant could become plugged by the $S_{r} F_{2}$ solids, especially near the pipe elbows and bends in the line. Such plugging could be avoided by crushing the $\mathrm{SrF}_{2}$ solids to 
$<300-\mu m$ size particles, mixing with at least 25 times as much volume of water, and sizing the vortex pump to deliver at least $3.048 \mathrm{~m} / \mathrm{s}$ (10-fps) fluid velocities.

In addition to the possibility of plugged transfer lines from WESF to

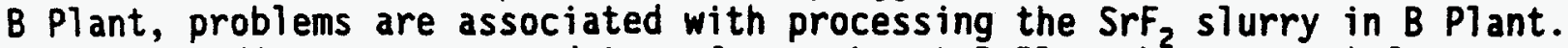
The intermediate storage and transfer tanks at B Plant have a much larger capacity (18.93 $\left.\mathrm{m}^{3}[5,000 \mathrm{gal}]\right)$, and the relatively small $\left(0.38-\mathrm{m}^{3}[100-\mathrm{gal}]\right)$ batch transfers from WESF will have to be mixed with large volumes of water to successfully transfer the majority of the highly radioactive solution at the 4 vol\% limit. This will drastically increase the total volume of capsule waste going to the HWVP.

An alternative to transferring $\mathrm{SrF}_{2}$ solids as a slurry is transporting them as solids from outside the WESF building in a truck to B Plant. However, this option would require a double-shielded cask meeting present regulations. Presently, a cask with an approved design is not available. In addition, there is also the problem of adding the $\mathrm{SrF}_{2}$ solids (powder) to the pretreated NCAW and/or CC waste in the B Plant.

\subsubsection{Blending of Cesium Chloride and Strontium Fluoride Solutions with Neutralized Current Acid Waste and/or Complexant Concentrate Waste and Transfer to Hanford Waste Vitrification Plant}

The blending of $\mathrm{CsCl}$ and $\mathrm{SrF}_{2}$ solutions with NCAW and/or CC waste is not expected to require any modifications to $B$ Plant. A series of jumpers exist within B Plant that would facilitate transfer of liquids from a given tank to any other tank within any cell of the B Plant. However, these jumpers may be committed for use in the processing of NCAW at B Plant, requiring the procurement and installation of new jumpers and associated piping and connections. The current pretreatment scheme requires that the NCAW supernatant be processed at B Plant to remove cesium. The NCAW solids will be processed at the 244-AR Vault and transferred to tank 102-AY. The cesium extracted from the NCAW supernatant also will be transferred to tank 102-AY for blending with the processed NCAW solids. The cesium and strontium from the capsules initially will be transferred to B Plant, and from there will be pumped to tank 102-AY for blending with the pretreated NCAW. The mixture then will be transferred to HWVP for vitrification. Instead of transferring separately, the cesium recovered from the NCAW supernatant and the cesium and strontium from the capsules could be pumped into a holding tank at B Plant, and the mixture could then be transferred to tank 102-AY.

Existing aging waste transfer systems, in conjunction with new aging waste transfer lines to be installed, will be used for transferring processed NCAW and capsule solutions from B Plant to tank 102-AY. The pretreated NCAW from tank 102-AY will be routed through Diversion Box Number 1 (located due south of the B Plant) to HWVP for vitrification. The transfer from tank 102-AY to Diversion Box Number 1 will be made using the existing lines and those installed under Project $W-028$. The final transfer from Diversion Box Number 1 to the HWVP will be performed using transfer lines to be constructed by the HWVP Project. 


\subsection{PRETREATHENT OF CESIUH CHLORIDE AND STRONTIUH \\ FLUORIDE BEFORE BLENDING HITH MEUTRALIZED \\ CURRENT ACID WASTE AND/OR COMPLEXANT \\ CONCENTRATE WASTE}

This option is similar to the direct blending option, and can also be carried out either in the WESF or the HWVP for both $\mathrm{CsCl}$ and $\mathrm{SrF}_{2}$ capsules.

Direct blending of $\mathrm{CsCl}$ and $\mathrm{SrF}_{2}$ salts with NCAW and/or CC waste feedstreams may produce a feed with a composition that is outside the HWVP design specifications. This would necessitate the removal of chlorine and fluorine from $\mathrm{CsCl}$ and $\mathrm{SrF}_{2}$ before blending with the waste feedstreams. This scenario identifies the facilities and equipment needed for the (1) removal of halides from the cesium and strontium salts, (2) transfer of the cesium/strontium solutions to B Plant, and (3) blending of the solutions with the NCAW and/or CC waste feedstreams.

The removal of $\mathrm{CsCl}$ and $\mathrm{SrF}_{2}$ salts from the capsules and disposal of solid wastes generated by these operations will be performed in the same manner as described in Section 6.3.

\subsubsection{Separation of Chloride from Cesium Chloride}

The two methods considered for separating $\mathrm{Cl}$ from $\mathrm{CsCl}$ are ion exchange and reaction with silver nitrate.

6.2.1.1 Ion Exchange. B Plant was used previously to dechlorinate $\mathrm{CsCl}$ and convert the cesium to a nitrate salt. A similar process could be used for the CsCl capsules. At WESF, the capsules would be opened and the $\mathrm{CSCl}$ dissolved in water. The dissolved $\mathrm{CSCl}$ would be transferred to $\mathrm{B} P \mathrm{Pl}$ ant and processed through ion-exchange columns. The flow diagram for the process is given in Figure 6-1. In a previous study, Cell 18 at B Plant was identified as a likely location for ion-exchange processing (PNL 1984).

The $\mathrm{CsCl}$ is first dissolved in water at WESF to a concentration of $0.5 \mathrm{M}$. The total volume of $\mathrm{CsCl}$ solution would be $42,800 \mathrm{~L}$. In a $380-\mathrm{L}$ capacity tank, there would be about 113 batches. On transfer to $B$ Plant, a holding tank would be needed. A 5,000-L tank would contain about 9 batches of CsCl solution.

Two ion-exchange columns would allow alternating processing and regeneration cycles. If the columns are $0.46 \mathrm{~m}$ in diameter $\times 3.7 \mathrm{~m}$ long (18 in. in diameter $\times 12 \mathrm{ft}$ long), they would have an effective resin capacity of $390 \mathrm{~L}$ (allowing 35\% of the bed for head space). The total amount of bed volume is based on an exchange capacity of 1.4 equivalents/L. At this rate, $15,300 \mathrm{~L}$ of effective resin volume would be used. If each bed is used for ten cycles before exhaustion, then each would be changed out once during the campaign, corresponding to an actual resin requirement of 1,530 L. The column is regenerated with $1 \mathrm{M} \mathrm{HNO}_{3}$. About $107,000 \mathrm{~L}$ of acid would be used. With a $5,000-L$ tank, about $2 \overline{1}$ batches of acid would be made up. The solution produced from regeneration is composed of cesium nitrate and $\mathrm{HNO}_{3}$. This solution has the same volume as the $\mathrm{HNO}_{3}$ regeneration solution and could be held in another 5,000-L tank for transfer to HWVP. 
WHC-EP-0460

Figure 6-1. Flow Diagram for Ion-Exchange Dechlorinization of Cesium Chloride.

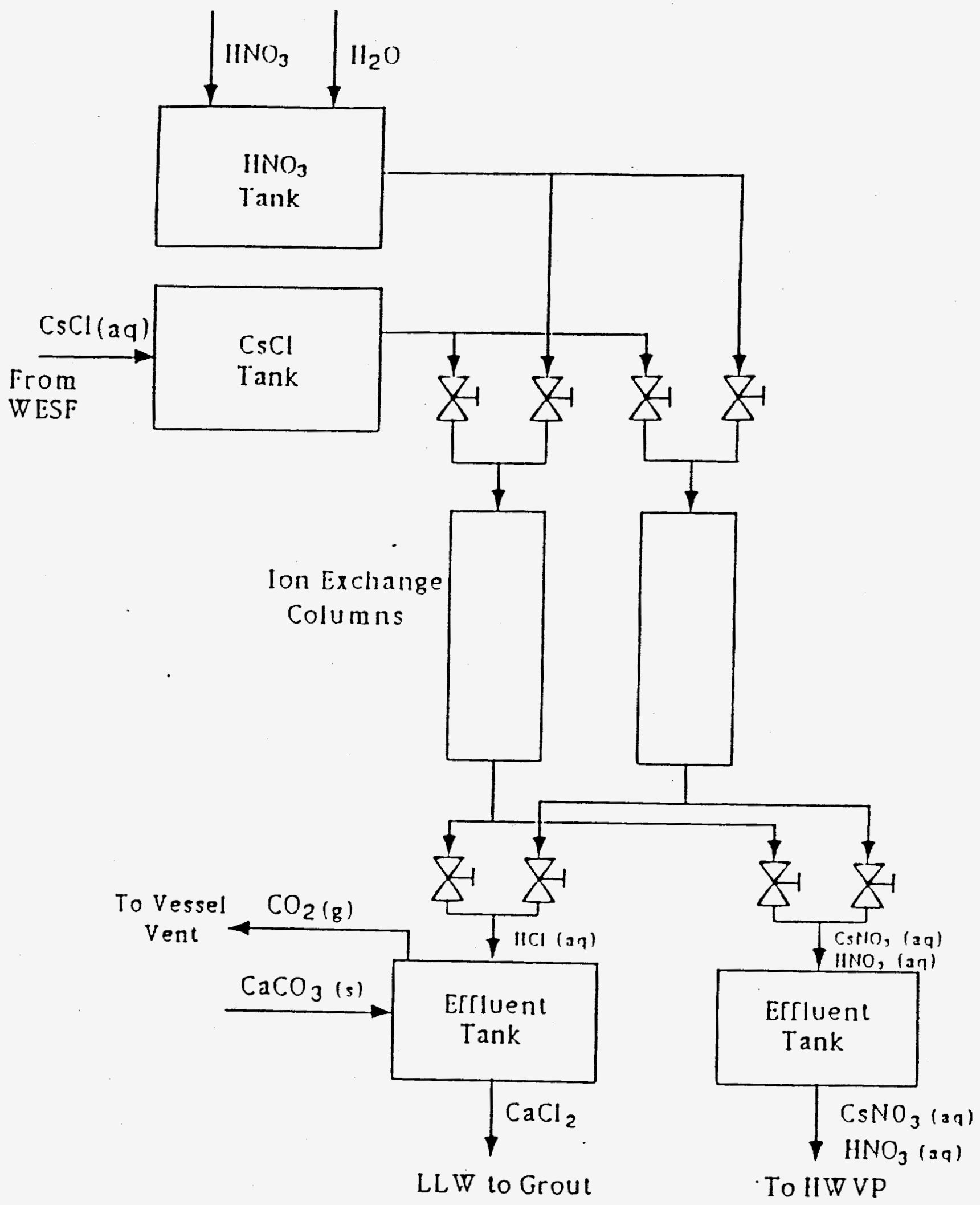


During ion exchange, $\mathrm{HCl}$ is discharged from the column and is collected in another holding tank. After neutralization with limestone, this waste stream could be sent for grout disposal. About $12,000 \mathrm{~L}_{\text {of }} \mathrm{CaCl}_{2}$ solution would be generated. With a 1,000-L tank, this low-level waste would be transferred for grout disposal 12 times.

6.2.1.2 Reaction with Silver Nitrate. As mentioned before, the separation of chloride from $\mathrm{CsCl}$ can be carried out either in WESF or HWVP. Figure 6-2 shows the flow diagram for the separation process. The process involves chopping the outer and inner capsules, dissolving the $\mathrm{CsCl}$ in water, mixing the $\mathrm{CsCl} /$ water solution with aqueous $\mathrm{AgNO}_{3}$ to precipitate chloride as $\mathrm{AgCl}$, separating the solid $\mathrm{AgCl}$ from the $\mathrm{CsNO}_{3}$ solution, and finally pumping the $\mathrm{CSNO}_{3}$ solution to B Plant (if capsule processing operations are performed at WESF) for blending with NCAW and/or CC waste.

Chopsaws can be used for dismantling the inner and outer capsule materials. The $\mathrm{CsCl}$ salt can be dissolved in water in a $0.19-\mathrm{m}^{3}$ (50-gal) tank and the $\mathrm{CsCl}$ solution can then be transferred to a $0.38-\mathrm{m}^{3}$ (100-gal) tank for treatment with $\mathrm{AgNO}_{3}$. The total volume of the $\mathrm{AgNO}_{3}$ and $\mathrm{CsCl}$ solutions involved in the chloride separation process is approximately $22.71 \mathrm{~m}^{3}$ $(6,000 \mathrm{gal})$. With a $0.38-\mathrm{m}^{3}(100-\mathrm{gal})$ process tank, the entire CsCl inventory can be processed in about 70 batches.

The next step is to separate the solid $\mathrm{AgCl}$ from aqueous $\mathrm{CsNO}_{3}$. This can be accomplished using a solid-liquid separation process currently being tested at the Chemical Engineering Laboratory for filtering the NCRW stimulant with a pneumatic hydropulse (PHP) filter. The filter used is a sintered stainless steel or Hastelloy metal filter of the required pore size. The filter housing consists of the metal filter through which the solution to be filtered is passed. Figure 6-3 is a schematic of a modified version of the test setup proposed for filtering the NCRW stimulant. As shown in the figure, the solution is pumped from the $0.38-\mathrm{m}^{3}(100-\mathrm{gal}) \mathrm{AgNO}_{3}$ treatment tank through the filter system into a filtrate collection tank. To keep the AgCl solids suspended, the $\mathrm{AgNO}_{3}$ treatment tank is agitated by means of a paddle agitator. The stirred solution is pumped until a specified minimum flow rate and/or a specified maximum pressure drop is reached. When these conditions are met, the valve at the exit of the $\mathrm{AgNO}_{3}$ treatment tank and the filtrate exhaust valve are closed.

The air inlet valve is opened to pressurize the backflush reservoir containing water to $0.55 \mathrm{MPa}(80 \mathrm{psi})$. The blowdown outlet valve is then opened, causing the water to discharge through the filter and forcing the filter cake into the blowdown collection vessel. Before opening the blowdown outlet valve, the majority of the liquid from the filter housing is pumped out into the filtrate collection tank to ensure that very little of the $\mathrm{CsNO}_{3}$ solution escapes into the collection vessel along with the $\mathrm{AgCl}$ solids. "The air pressure valve and blowdown valve are closed. The feed valve and the filtrate exhaust valve are opened. The air is bled from the system and the cycle is repeated. The $\mathrm{AgCl}$ filter cake is dried and transported to $\mathrm{B}$ Plant canyon for burial as solid waste. The solid $\mathrm{AgCl}$ waste is considered to be mixed waste because $A g C l$ is hazardous. The mixed waste should be packaged in accordance with appropriate regulations, transported according to DOT-49 CFR, 
Figure 6-2. Flow Diagram for Processing Cesium Chloride to Remove Chloride.

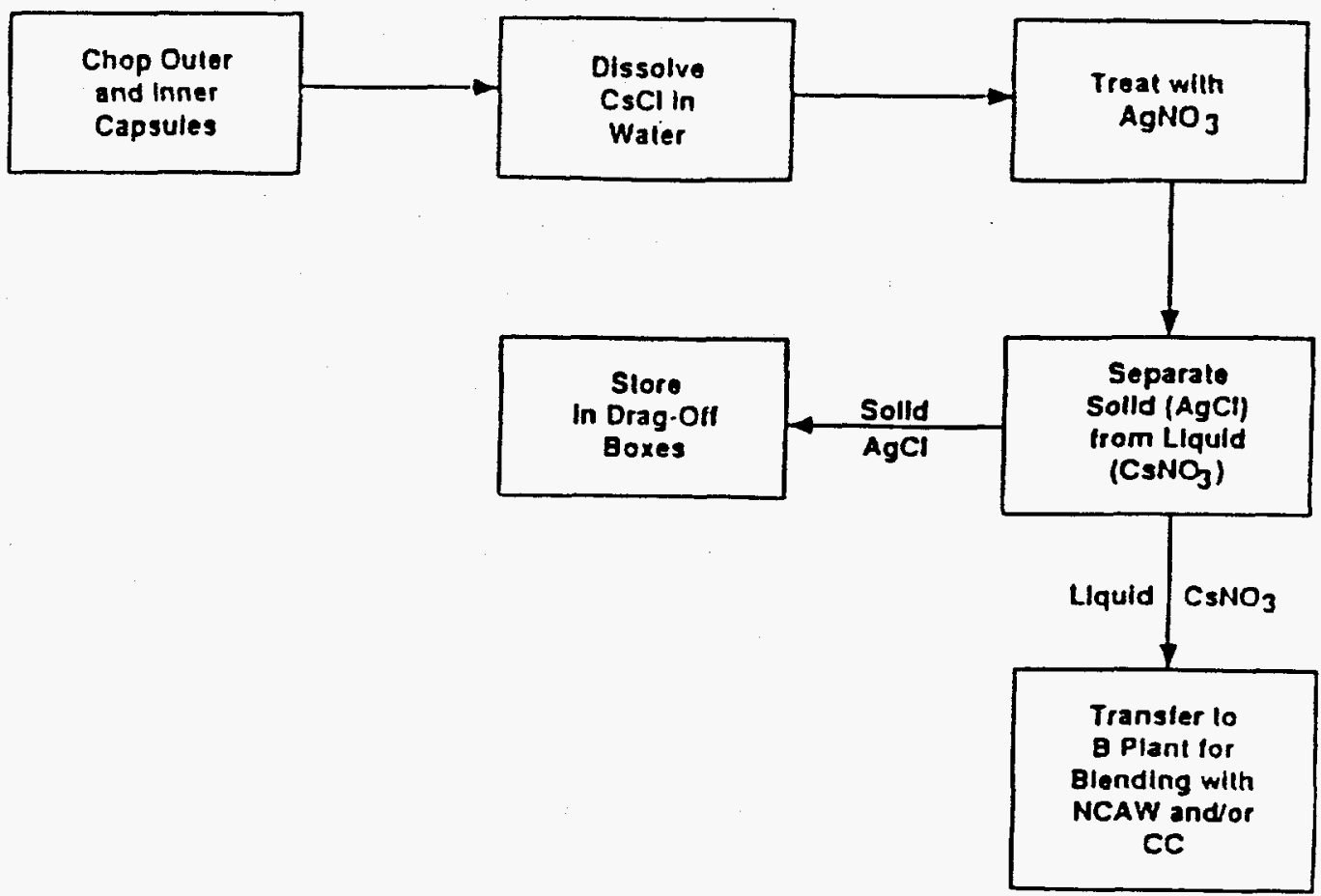


Figure 6-3. Schematic of Filter System for Separating Silver Chloride from Cesium Nitrate.

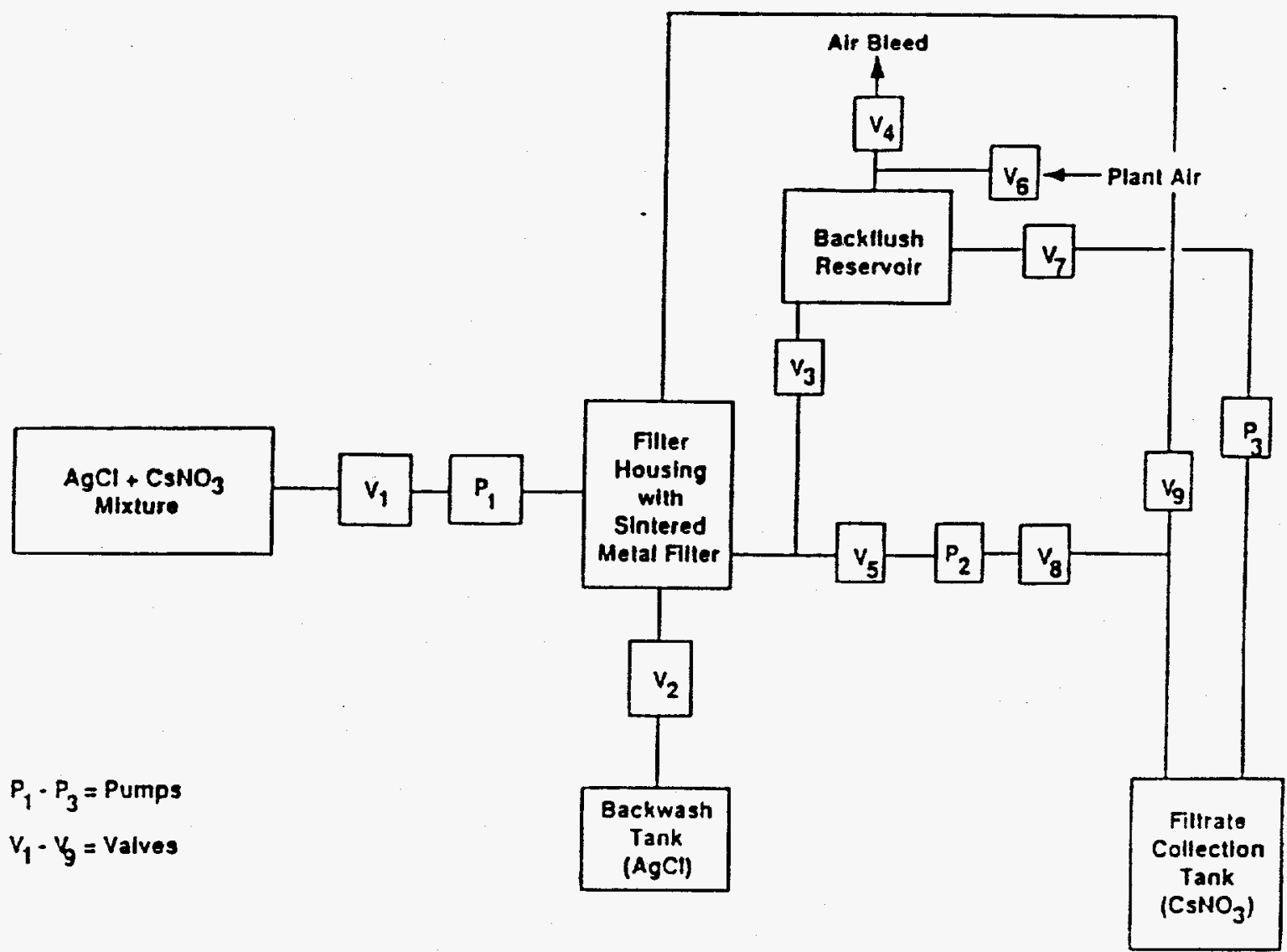


and stored in the central waste complex for future retrieval and shipping to a mixed waste storage facility. The $\mathrm{CsNO}_{3}$ solution is dumped in the sump and transferred to $B$ Plant using steam jets.

\subsubsection{Separation of Fluoride from Strontium Fluoride}

The separation of fluoride from $\mathrm{SrF}_{2}$ can also be carried out in the chemical process $D / E$ Cell at WESF. The flow diagram for the separation process is shown in Figure 6-4.

As schematically illustrated in the figure, the separation process involves chopping the outer and inner capsules with modified chopsaws, breaking the $\mathrm{SrF}_{2}$ salt loose from the Hastelloy capsule into several pieces, pulverizing the $\mathrm{SrF}_{2}$ pieces into particles of $\leq 300 \mu m$ (number 50 sieve) size, dissolving in sulfuric acid to convert to $\mathrm{SrSO}_{4}$, treating with aqueous sodium carbonate to convert to $\mathrm{SrCO}_{3}$, dissolving in $\mathrm{HNO}_{3}$ to transform to soluble $\mathrm{Sr}\left(\mathrm{NO}_{3}\right)_{2}$, and finally pumping to $\mathrm{B}$ Plant for blending with NCAW and/or CC waste.

The steps involving chopping, hammering and chiseling, and pulverizing are the same as those described in Section 6.3 .2 for processing $\mathrm{SrF}_{2}$, where fluoride separation is not required. These operations can be performed either in the $D$ or $E$ portion of the $D / E$ cell of the WESF.

The pulverized $\mathrm{SrF}_{2}$ powder is then dissolved in sulfuric acid for conversion to solid $\mathrm{SrSO}_{4}$. A stoichiometric amount of $0.81 \mathrm{~m}^{3}$ (215 gal) of concentrated $\mathrm{H}_{2} \mathrm{SO}_{4}(18 \mathrm{M})$ is needed to dissolve the $\mathrm{SrF}_{2}$. However, this amount needs to be increased by $20 \%$ to $0.98 \mathrm{~m}^{3}$ (258 $\left.\mathrm{gal}\right)$ to ensure that most of the inventory of $\mathrm{SrF}_{3}$ is dissolved. Thus, the total volume of $\mathrm{SrF}_{2}$ and $\mathrm{H}_{2} \mathrm{SO}_{4}$ will be about $1.61 \mathrm{~m}^{32}(425 \mathrm{gal})$. Using a $0.08-\mathrm{m}^{3}$ (20-gal) tank, the entire operation of dissolution of $\mathrm{SrF}_{2}$ in $\mathrm{H}_{2} \mathrm{SO}_{4}$ can be carried out in about 40 batches, assuming the effective volume of the tank to be about $75 \%$. According to the flowsheet, this reaction is hastened by agitation and an increase in temperature and, therefore, the $\mathrm{SrF}_{2}$ and $\mathrm{H}_{2} \mathrm{SO}_{4}$ initially will be mixed in the $0.08-\mathrm{m}^{3}(20-\mathrm{gal})$ tank and transferred to an externally heated rotating furnace of the same capacity operated at $100^{\circ} \mathrm{C}$ to $130^{\circ} \mathrm{C}$. The $\mathrm{SrF}_{2}$ and $\mathrm{H}_{2} \mathrm{SO}_{4}$ mixture will be kept in the furnace at the specified temperature for approximately $2 \mathrm{~h}$ after which time the conversion of $\mathrm{SrF}_{2}$ to $\mathrm{SrSO}_{4}$ for the most part is expected to be complete. Besides $\mathrm{SrSO}_{4}$, the other byproduct of the reaction between $\mathrm{SrF}_{2}$ and $\mathrm{H}_{2} \mathrm{SO}_{4}$ is $\mathrm{HF}$, which is in gaseous form and will be directed into the offgas treatment system. Presentiy, there is no offgas treatment system in WESF. Such systems have not been required since previous operations at WESF primarily involved encapsulation of $\mathrm{CSCl}_{1}$ and $\mathrm{SrF}_{2}$, and only more recently were some CSCl capsules disassembled and processed. Bisassembiy and processing of the $\mathrm{CsCl}$ capsules did not require elaborate chemical processing steps. However, gaseous wastes were filtered through at least two stages of high-efficiency particulate air (HEPA) filters before release to the atmosphere. 
Figure 6-4. Flow Diagram for Processing Strontium Fluoride to Remove Fluoride.

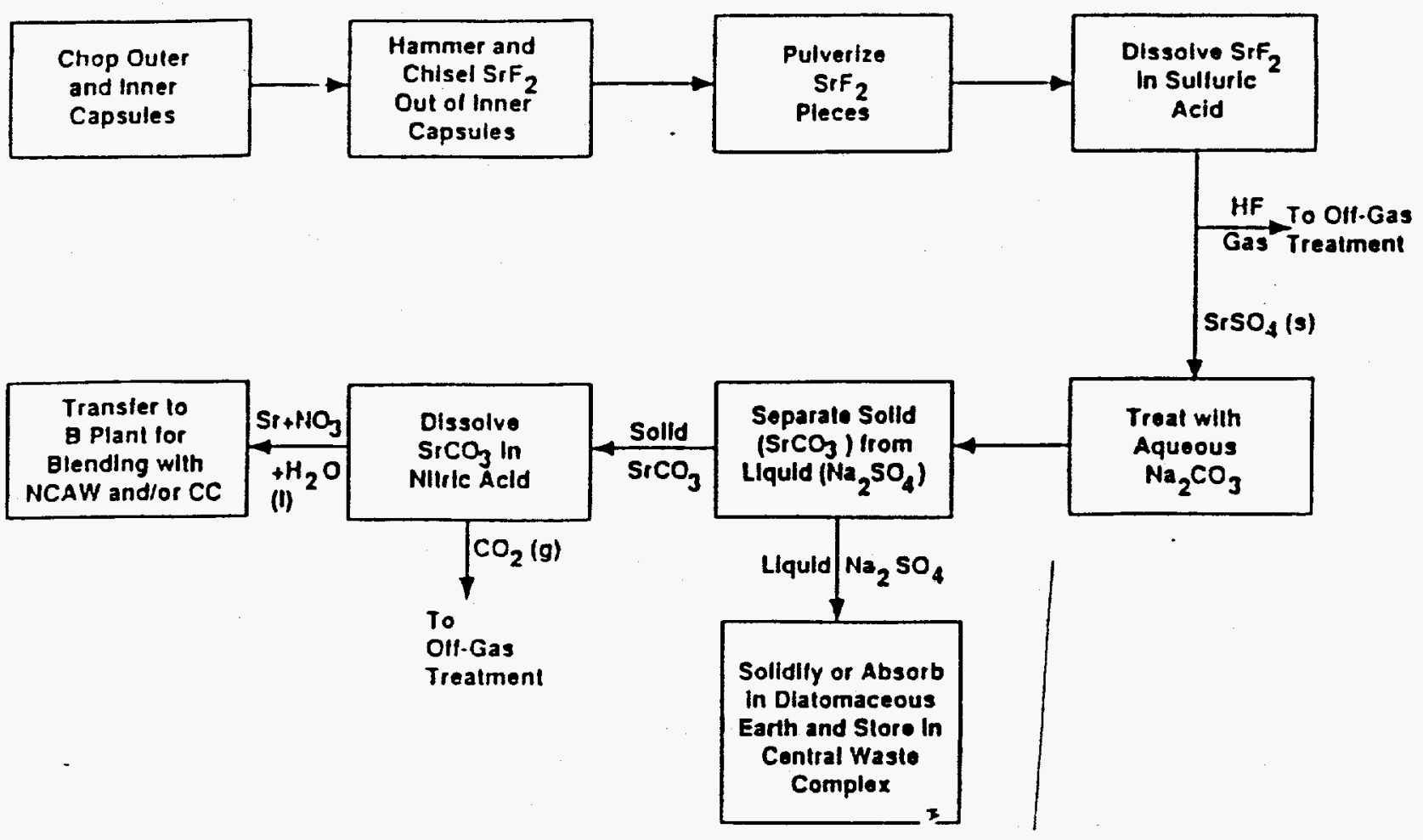


The generation of gaseous HF requires an offgas treatment system that would convert the majority of the HF gas to a nonhazardous substance and eventually release vapors containing permissible levels of HF to the atmosphere. The treatment involves neutralizing the HF with $\mathrm{KOH}$ to generate $K F$. However, $K F$ is considered to be a dangerous substance by the Washington Administrative Code (WAC). Therefore, KF will be treated with $\mathrm{MgO}$ (and $\mathrm{H}_{2} \mathrm{O}$ ), which will convert most of the $\mathrm{KF}$ to $\mathrm{MgF}_{2}$ and will regenerate $\mathrm{KOH}$. The low solubility of $\mathrm{MgF}_{2}$ and $\mathrm{MgO}$ facilitates filtering from the liquor, leaving a regenerated $\mathrm{KOH}$. The $\mathrm{MgF}_{2}$ and $\mathrm{MgO}$ are not currentiy regulated waste according to WAC and possibly can be disposed of in drag-off boxes with solid capsule materials waste. The remaining $\mathrm{KOH}$ can be used again for further treatment of $\mathrm{HF}$. The quantities of $\mathrm{KOH}$ and $\mathrm{MgO}$ required for treatment of the entire inventory of HF gas are $1,458.02 \mathrm{~kg}$ and $1,046.34 \mathrm{~kg}$, respectively. Monel 400 can be used effectively as a containment material to resist corrosion by the offgas condensate.

Conversion of $\mathrm{SrSO}_{4}$ to $\mathrm{SrCO}_{3}$ by reaction with $\mathrm{Na}_{2} \mathrm{CO}_{3}$ is an effective way to reduce the total $\mathrm{SO}_{4}$ going into the HWVP feedstreams. Any unreacted solid $\mathrm{SrF}_{2}$ remaining from treatment with $\mathrm{H}_{2} \mathrm{SO}_{4}$ will be unaffected by the metathesis with $\mathrm{Na}_{2} \mathrm{CO}_{3}$.

The stoichiometric amount of solid $\mathrm{Na}_{2} \mathrm{CO}_{3}$ required to convert the entire inventory of $\mathrm{SrSO}_{4}$ is $2,120 \mathrm{~kg}$. However, since aqueous $\mathrm{Na}_{2} \mathrm{CO}_{3}$ is needed for this reaction, this translates to $10.61 \mathrm{~m}^{3}(2,804 \mathrm{gal})$ of $2 \mathrm{M}$ Yiquid $\mathrm{Na}_{2} \mathrm{CO}_{3}$. Taking into account the effective volume of the tank, the total adjusted amount of the $\mathrm{SrSO}_{4}+\mathrm{Na}_{2} \mathrm{CO}_{3}$ mixture is about $15.14 \mathrm{~m}^{3}(4,000 \mathrm{gal})$. By making use of a $0.38-\mathrm{m}^{3}$ (100-gal) tank, the entire $\mathrm{SrSO}_{4}$ inventory can be processed in 40 batches. Because of the limited solubility of $\mathrm{SrSO}_{4}$, the $\mathrm{SrSO}_{4} / \mathrm{Na}_{2} \mathrm{CO}_{3}$ mixture will be agitated to ensure completion of the metathes is in a matter of hours. As a byproduct of this metathesis, $2,161 \mathrm{~kg}$ of $\mathrm{Na}_{2} \mathrm{SO}_{4}$ is produced as liquid waste along with a small amount of $\mathrm{Na}_{2} \mathrm{CO}_{3}$. The separation of solid $\mathrm{SrCO}_{3}$ (and any unreacted $\mathrm{SrF}_{2}$ ) from the liquid waste can be accomplished using the PHP filter system described in Section 6.4.1. The liquid waste will be solidified or absorbed in diatomaceous earth for transportation and disposal as solid waste. However, the hazardous nature of the waste must be assessed. If the waste is hazardous it will be packaged with enough shielding to reduce the dose rate to $<200 \mathrm{mR} / \mathrm{h}$ and stored in the central waste complex for future retrieval, If the waste is classified as nonhazardous, it will be transported in $0.21-\mathrm{m}^{3}(55-\mathrm{ga})$ ) drums to the B Plant canyon for storage in drag-off boxes for eventual burial with contaminated equipment.

The $\mathrm{SrCO}_{3}$ produced by the metathesis of $\mathrm{SrSO}_{4}$ with aqueous $\mathrm{Na}_{2} \mathrm{CO}_{3}$ can be directly transferred to $B$ Plant as a slurry in water for blending with the NCAW and/or CC feedstreams. This transfer is similar to the slurry transfer of $\mathrm{SrF}_{2}$ described in Section 6.3.2. Therefore, the entire inventory of $\mathrm{SrCO}_{3}$ solids will require approximately $15.14 \mathrm{~m}^{3}(4,000 \mathrm{gal})$ of water. The $\mathrm{SrCO}_{3}$ solids will be mixed with water in a $0.38-\mathrm{m}^{3}$ (100-gal) tank and transferred to the B Plant for further processing in 53 batches. As before, the success of this operation strongly depends on the capability of the vortex pump, which will be used to pump the slurry without any plugging of the transfer 1 ines.

The uncertainty of plugged transfer lines can be eliminated by transferring strontium in liquid form rather than solid form. The $\mathrm{SrCO}_{3} \mathrm{Can}$ be dissolved in $\mathrm{HNO}_{3}$ to yield a $\mathrm{Sr}\left(\mathrm{NO}_{3}\right)_{2}$ solution to be mixed with the 
reference feed. Equilibrium calculations indicate that the entire inventory of $\mathrm{SrCO}_{3}$ would require $26 \mathrm{~m}^{3}(6,868 \mathrm{gal})$ of $1 \mathrm{M} \mathrm{HNO}_{3}$. Assuming the actual amount of $\mathrm{HNO}_{3}$ used to be $25 \%$ more than the stoichiometric amount yields $32.5 \mathrm{~m}^{3}(8,586 \mathrm{gal})$ of $\mathrm{HNO}_{3}$. Considering that only $75 \%$ of the volume of any given tank can be used effectively, the entire inventory would require 117 batches for transfer to B Plant using a $0.38-\mathrm{m}^{3}$ (100-gal) tank.

\subsubsection{Blending of Cesium Nitrate and Sodium Nitrate Solutions with Neutralized Current Acid Waste and/or Complexant Concentrate Waste and Transfer to the Hanford Haste Vitrification Plant}

The blending of $\mathrm{CsNO}_{3}$ and $\mathrm{Sr}\left(\mathrm{NO}_{3}\right)_{2}$ solutions with NCAW and/Or CC waste is not expected to require any modifications to the $B$ Plant. However, processing of the capsule waste at WESF to remove the chloride and fluoride will make the resulting solutions quite acidic. These solutions will have to be neutralized either in tank TK-25-1 or before transfer to tank TK-25-1 before blending with the NCAW waste. The combined presence of free fluoride and acid solutions is normally a cause for concern for the integrity of the storage and treatment tanks. However, in the present case, the B Plant tanks will be exposed to acid capsule wastes with free fluoride for a relatively short period of time. The acid wastes are quickly neutralized to reduce their corrosion potential. In addition, the fluoride concentration of the HWVP waste feed is expected to increase from 0.3 to only 0.37 by blending the capsule waste.

As discussed in Section 6.1.3, the processed capsule solutions will be blended with the pretreated NCAW solutions in tank 102-AY and eventually transferred to HWVP for vitrification.

\subsection{HANFORD WASTE VITRIFICATION PLANT FACILITIES AND REQUIRED MODIFICATIONS}

The removal of the $\mathrm{CsCl}$ and $\mathrm{SrF}_{2}$ salts from the capsules and processing of the capsules can be performed in the HWVP. One of the laydown areas in HWV can be modified to provide the necessary capabilities. Laydown space would have to be identified el sewhere in the facility. The same equipment described in Section 6.1 would be required for this work. Additional HWVP-specific equipment is (1) two shielded windows, (2) a remote camera, (3) lining and coverblocks for the cell, (4) four master-slave manipulators, (5) a 2.5-ton hoist, (6) in-cell lighting, (7) process water, stream, and air service, (8) a sump, jet and regulated drain to the decontamination treatment tank, (9) two doubly encased process lines to the SRAT, and (10) three stainless steel vessels and associated agitators, transfer jets and piping. 


\section{WHC-EP-0460}

This page intentionally left blank. 
WHC-EP-0460

This page intentionally left blank. 
WHC-EP-0460

\subsection{COST ESTIMATES}

This section describes the cost estimates for (1) storing the capsules indefinitely, (2) overpacking the capsules and shipping them to the repository, and (3) processing the capsules through HWVP.

\subsection{INDEFINITE STORAGE OF CAPSULES}

If it is decided to continue storing the capsules until the cesium and strontium have decayed to low levels, a new storage facility similar to WESF must be constructed by the year 2005 and operated until the year 2300 . The facility would cost about $\$ 200$ million to construct and approximately $\$ 20 \mathrm{million} / \mathrm{yr}$ to operate in fiscal year (FY) 1990 dollars. The total cost for indefinite (i.e., $300 \mathrm{yr}$ ) storage of capsules is, therefore, \$6.l billion dollars in FY 1990 dollars.

\subsection{OVERPACK THE CAPSULES AND SHIP TO REPOSITORY}

The preferred alternative for capsule disposal as described in the HDW-EIS will generate 496 canisters for emplacement in the high-level waste repository. The current repository disposal fee for borosilicate glass is $\$ 350,000$ per canister (Federal Register, Vo1. 52, No. 161). Thus, this scenario will entail $\$ 174$ million in repository disposal costs. In addition to this, it is expected that facility modifications, canister procurement, labor, and other costs associated with overpacking the capsules will cost approximately $\$ 76$ million. The total cost for capsule disposal for this option is estimated at $\$ 250$ million.

\subsection{PROCESS CAPSULES THROUGH THE HANFORD WASTE VITRIFICATION PLANT}

\subsubsection{Blend Cesium Chloride and Strontium Fluoride Directly with Meutralized Current Acid Waste and/or Complexant Concentrate Waste}

This option requires the removal of $\mathrm{CsCl}$ and $\mathrm{SrF}_{2}$ salts from the capsules and blending directly with NCAW and/or CC waste without processing to remove the halides. As mentioned in Section 6.3, this work can be carried out in the WESF. The outer capsules will be removed in $G$ Cell by cutting off the welded end caps with chopsaws. Then, the inner capsules will be transferred to E Cell for cutting off the weided end caps with chopsaws and processing the $\mathrm{CsCl}$ and $\mathrm{SrF}_{2}$ salts. The cutting and processing operations for $\mathrm{CsCl}$ are relatively simple compared to those for $\mathrm{SrF}_{2}$. Chopsaws similar to those used previously at WESF for cutting the CSCl capsules will be used again for cutting the CsCl capsules. The design will be improved, however, for more efficient operations. The chopsaw design needs to be modified for $\mathrm{SrF}_{2}$ to make the longitudinal cuts. It is proposed in Section 6.4 .2 to use a $3.38-\mathrm{m}^{3}$ (100-gal) tank for processing the SrF 2 slurry; the same tank also can be used for dissolving $\mathrm{CsCl}$ in water. Therefore, the equipment needed to carry out 
this option at WESF includes chopsaws, pulverizers (jaw crushers), a $0.38-m^{3}$ (100-gal) tank with agitator, and a vortex pump. The itemized list of equipment and material costs is given in Table 7-1. The cost for equipment and materials for this option is $\$ 150,000$. This cost includes piping and installation, and minor decontamination of cells. Extensive decontamination is not required since the installation is performed remotely.

Table 7-1. Cost Estimate for the Equipment Required for Processing Cesium Chloride and Strontium Fluoride at the Waste Encapsulation and Storage Facility for Direct Blending with Neutralized Current Acid Waste and/or Complexant Concentrate Waste.

\begin{tabular}{|l|l|c|c|l|c|}
\hline \multicolumn{1}{|c|}{ Item } & Location & Quantity & Capacity & \multicolumn{1}{|c|}{ Material } & $\begin{array}{c}\text { Cost } \\
(\$ 1,000)\end{array}$ \\
\hline Chopsaw & $\begin{array}{l}\text { WESF G Cell } \\
\text { and E Cell }\end{array}$ & 4 & -- & $\begin{array}{l}\text { Carbide steel } \\
\text { blade }\end{array}$ & 60 \\
\hline Pulverizer & WESF E Cell & 2 & $\begin{array}{l}318- \\
364 \mathrm{~kg} / \mathrm{h}\end{array}$ & $\begin{array}{l}\text { Ni-hard } \\
\text { crushing } \\
\text { plates }\end{array}$ & 30 \\
\hline $\begin{array}{l}\text { Mixing/ } \\
\text { dissolving } \\
\text { tank }\end{array}$ & WESF E Cell & 1 & $\begin{array}{l}0.38 \mathrm{~m}^{3} \\
\left(100 \mathrm{gal}^{\prime}\right)\end{array}$ & $316 \mathrm{~L}$ & 20 \\
\hline $\begin{array}{l}\text { Vortex pump } \\
\text { WESF E Cell }\end{array}$ & 1 & $\begin{array}{l}1 \mathrm{HP} / \\
20 \mathrm{gal} / \mathrm{min}\end{array}$ & $316 \mathrm{~L}$ & 5 \\
\hline $\begin{array}{l}\text { Piping and } \\
\text { installation }\end{array}$ & & & & & 25 \\
\hline $\begin{array}{l}\text { Decontamina- } \\
\text { tion of } \\
\text { cells }\end{array}$ & & & & & 10 \\
\hline \begin{tabular}{l} 
Total \\
\hline
\end{tabular} & & & & & 150. \\
\hline
\end{tabular}

The only byproduct waste that is generated for this option is the solid waste associated with the disassembly of the inner and outer capsule materials. The cut up inner capsule materials will be disposed of in drag-off boxes from the B Plant canyon. The cut up outer capsule materials will be disposed of in low-level waste burial grounds. The capsules that were presumed to be leaking will have a third containment capsule. In this case, all three containment materials will be disposed of in drag-off boxes. The cost for solid waste disposal is estimated to be $\$ 180,000$ assuming the dragoff box costs $\$ 150,000$.

In addition to the costs above, costs are incurred for the operation of WESF, B Plant, 244-AR Vault, tank farms, and HWVP for processing the capsule wastes. 
The WESF operations require five operators per $8-h$ shift. There are 4 shifts per week for around-the-clock coverage, which requires a total of 20 full-time operators. In addition, 10 surveillance support personnel are needed. Therefore, total manpower required for WESF operations is 30 .

Assuming that it takes 1 wk to process $48 \mathrm{CsCl}$ capsules (estimate based on previous WESF experience), the time to process all $1,349 \mathrm{CsCl}$ capsules will be 28 wk. However, about $40 \%$ downt ime will be needed for activities such as general maintenance, manipulator replacement, and operator training. Therefore, the estimated total time for $\mathrm{CsCl}$ capsule processing is about $1 \mathrm{yr}$. The time required to process $\mathrm{SrF}_{2}$ capsules can be calculated in a similar way using ORNL experience as a basis. The result is $177 \mathrm{~d}$ to process all 636 capsules. However, since slurry transfers may incur plugging problems, this time should be increased by 25\%. Therefore, the total time to process all $636 \mathrm{SrF}_{2}$ capsules will be approximately $0.75 \mathrm{yr}$.

Thus, the WESF will be operating for a total of $1.75 \mathrm{yr}$. Assuming a workforce cost of $\$ 85,000 /$ workyear, the cost of operating the WESF to process all the $\mathrm{CsCl}$ and $\mathrm{SrF}_{2}$ capsules for blending directly into NCAW and/or CC waste at B Plant will be $\$ 4.5$ million in FY 1990 dollars.

The existing safety analysis report (SAR) for the WESF may have to be modified because disassembly and processing of capsules for cesium and strontium disposal represents a mission change. In addition to a mission change, the processing of capsules at WESF may lead to generation of gases and/or airborne contamination containing radioactive substances. The cost to do the modification to the WESF SAR is estimated at $\$ 400,000$.

Therefore, the total cost for the option of processing capsules at WESF for direct blending with NCAW and/or CC waste is $\$ 4.9$ million in FY 1990 dollars.

The incremental cost of operating B Plant and other facilities such as the 244-AR Vault and tank farms for the processing of the capsule waste is not expected to be significant compared to the total cost of the capsule disposal mission. This is especially true for B Plant because the B Plant will be in operation for the processing of NCAW and TRUEX processing of other wastes, which includes several million gallons of liquid waste. However, a vortex pump is needed to transfer SrF, slurry between tanks at B Plant, which will require minor modification of the $B$ Plant. This extra cost is estimated to be $\$ 1$ million when considering the increase in the volume of waste after diluting the waste with water. The waste would be diluted so that a liquid heel of high radioactivity does not remain in the rather large tanks at $B$ Plant. Another additional cost may be modification of the SAR for B Plant, 244-AR Vault, and tank farms. The cost of SAR modification is estimated to be a total of approximately $\$ 1.2$ million for all three facilities.

The capsule waste blended into NCAW and/or CC waste is estimated to increase the number of canisters produced at HWVP by a maximum of 5 . At $\$ 500,000$ per canister (including HWVP operating costs), the incremental cost is $\$ 2.50$ million. Thus, the total cost for the direct blending of capsules with NCAW and/or CC waste is $\$ 9.6$ million in FY 1990 dollars. 


\subsubsection{Pretreatment of Cesium Chloride and Strontium Fluoride Before Blending with Neutralized Current Acid Waste and/or Complexant Concentrate Waste}

The procedure and equipment required to remove the $\mathrm{CsCl}$ and $\mathrm{SrF}_{2}$ from the metal capsules are identical to those described for the option in Section 7.3. The separation of $\mathrm{CsCl}$ requires one tank for dissolving the $\mathrm{CsCl}$ and a second tank for treating the aqueous $\mathrm{CsCl}$ with $\mathrm{AgNO}_{3}$. A PHP filter assembly is required to separate the solid $\mathrm{AgCl}$ from aqueous $\mathrm{CsNO}_{3}$. As described in Section 6.4.2, the separation of $\mathrm{SrF}_{2}$ is more involved and requires more equipment compared to that for $\mathrm{CsCl}$. Initially there is treatment with $\mathrm{H}_{2} \mathrm{SO}_{4}$ to dissolve the fluoride, which results in the release of $\mathrm{HF}$ gas as a byproduct that should be handled with an offgas treatment system. This is followed by a treatment with aqueous $\mathrm{Na}_{2} \mathrm{CO}_{3}$ to convert the $\mathrm{SrSO}_{4}$ to $\mathrm{SrCO}_{3}$. A PHP filter assembly can is used to separate solid $\mathrm{SrCO}_{3}$ from $Y$ iquid $\mathrm{Na}_{2} \mathrm{SO}_{4}$. The final step is dissolving the $\mathrm{SrCO}_{3}$ in $1 \mathrm{M} \mathrm{HNO}_{3}$ to convert $\mathrm{SrCO}_{3}$ into soluble $\mathrm{Sr}\left(\mathrm{NO}_{3}\right)_{2}$ for final transfer to $\mathrm{B}$ Plant. The costs of equipment and chemicals required for processing $\mathrm{CSCl}$ and $\mathrm{SrF}_{2}$ to separate the halides at WESF are itemized in Tables 7-2 and 7-3. The cost of equipment and materials for this option is $\$ 560,000$. As before, this cost also includes piping and installation and minor decontamination of cells. The cost of chemicals required for processing is $\$ 569,000$. This cost may be increased by $10 \%$ to cover the cost to prepare some of the solutions and to purchase chemicals in batches smaller than bulk quantities. This raises the total cost of chemicals to $\$ 626,000$.

The solid wastes generated for this option are the cut-up inner and outer capsule materials and $\mathrm{AgCl}$. As described in Section 7.3, the cut-up capsule materials will be disposed of in drag-off boxes and the costs will be the same as for the direct blending option. The solid $\mathrm{AgCl}$ waste is considered to be mixed waste. The mixed waste should be packaged in containers recommended by the Safety Analysis Report for Packaging (SARP) for the WESF, transported according to DOT-49 CFR, and stored in the central waste complex for future retrieval. The cost for the solid $\mathrm{AgCl}$ waste disposal is estimated to be $\$ 40,000$. Therefore, the cost for solid waste disposal is $\$ 240,000$.

In addition to the solid wastes, the separation of the halides also results in the production of liquid wastes $\left(\mathrm{Na}_{2} \mathrm{SO}_{4}, \mathrm{Na}_{2} \mathrm{CO}_{3}\right.$, and $\left.\mathrm{H}_{2} \mathrm{CO}_{3}\right)$. Since the volume of $\mathrm{Na}_{2} \mathrm{CO}_{3}$ in solution exceeds $10 \%$, the iqquid waste wi7l be classified as mixed waste. Similar to the methods used for $\mathrm{AgCl}$, the waste should be packaged in containers recommended by the SARP for the WESF, transported according to DOT-49 CFR, and stored in the central waste complex for future retrieval. The estimated cost for the liquid waste disposal is approximately $\$ 1,060,000$.

Assuming the WESF operating costs are $50 \%$ more than those for the direct blending option, and the costs for WESF SAR modification are the same as those for the direct blending option, the total cost for the option of processing capsules at WESF by removing the halides before blending with NCAW and/or CC waste is $\$ 10.2$ million in FY 1990 dollars. 
Table 7-2. Cost Estimate for the Equipment Required to Separate the Halides from Cesium Chloride and Strontium Fluoride at the Waste Encapsulation and Storage Facility Before Blending with Neutralized Current Acid Waste and/or Complexant Concentrate Waste."

\begin{tabular}{|c|c|c|c|c|c|}
\hline Item & Location & Quantity & Capacity & Material & $\begin{array}{l}\text { Cost } \\
(\$ 000)\end{array}$ \\
\hline Chopsaw & $\begin{array}{l}\text { WESF G Cell } \\
\text { and E Cell }\end{array}$ & 4 & -- & $\begin{array}{l}\text { Carbide steel } \\
\text { blade }\end{array}$ & 60 \\
\hline Pulverizer & WESF E Cell & 2 & $\begin{array}{l}318- \\
364 \mathrm{~kg} / \mathrm{h}\end{array}$ & $\begin{array}{l}\text { Ni-hard } \\
\text { crushing } \\
\text { plates }\end{array}$ & 30 \\
\hline \multirow{2}{*}{$\begin{array}{l}\text { Mixing/ } \\
\text { dissolving } \\
\text { tank }\end{array}$} & WESF E Cell & 1 & $\begin{array}{l}0.08 \mathrm{~m}^{3} \\
\left(20 \mathrm{gal}^{2}\right)\end{array}$ & $316 \mathrm{~L}$ & 5 \\
\hline & & 2 & $\begin{array}{l}0.38 \mathrm{~m}^{3} \\
\left(100 \mathrm{gal}^{2}\right)\end{array}$ & $316 \mathrm{~L}$ & 40 \\
\hline $\begin{array}{l}\text { Rotating } \\
\text { furnace }\end{array}$ & WESF E Cell & 1 & $\begin{array}{l}0.08 \mathrm{~m}^{3} \\
(20 \mathrm{gal})\end{array}$ & $316 \mathrm{~L}$ & 15 \\
\hline $\begin{array}{l}\text { Offgas } \\
\text { treatment } \\
\text { System }\end{array}$ & WESF E Cell & 1 & -- & Mone1-400 & 200 \\
\hline $\begin{array}{l}\text { PHP filter } \\
\text { system }\end{array}$ & WESF D Cell & 1 & -- & $316 \mathrm{~L}$ & 100 \\
\hline $\begin{array}{l}\text { Piping and } \\
\text { installation }\end{array}$ & & & & & 100 \\
\hline $\begin{array}{l}\text { Decontamina- } \\
\text { tion of } \\
\text { cells }\end{array}$ & & & & & 10 \\
\hline Total & & & & & 560 \\
\hline
\end{tabular}

The difference in equipment cost between pumping the $\mathrm{SrCO}_{3}$ slurry directly to $\mathrm{B}$ Plant versus dissolving in $\mathrm{HNO}_{3}$ and pumping liquid $\mathrm{Sr}\left(\mathrm{NO}_{3}\right)_{2}$ is negligible.

The same tanks, offgas system, and PHP filter system will be used to process both $\mathrm{CsCl}$ and $\mathrm{SrF}_{2}$. 
Table 7-3. Cost Estimate for the Chemicals Required to Separate the Halides from Cesium Chloride and Strontium Fluoride.

\begin{tabular}{|c|c|c|}
\hline Item & Quantity & Cost (\$) \\
\hline Sulfuric acid (18M) & $1.14 \mathrm{~m}^{3}(300 \mathrm{gal})$ & 600 \\
\hline Sodium carbonate & $2,120 \mathrm{~kg}$ & 650 \\
\hline Nitric acid $(1 M)^{a}$ & $32.18 \mathrm{~m}^{3}(8,500 \mathrm{gal})$ & 34,000 \\
\hline Potassium hydroxide $(5 \underline{M})^{\circ}$ & $9.46 \mathrm{~m}^{3}(2,500 \mathrm{gal})$ & 7,500 \\
\hline Magnesium oxide & $1,045 \mathrm{~kg}$ & 730 \\
\hline Silver nitrate & $3,675 \mathrm{~kg}$ & 525,525 \\
\hline Total & & 569,000 \\
\hline
\end{tabular}

QQuotation from W. H. Baddley, Chairman, Baddley Chemicals

Incorporated, to Bob Hunter, Westinghouse Hanford (August 28, 1990).

Quotation from Ken Quailes, Quality Discounts, Distributor for

J. T. Baker, Inc. (August 28, 1990).

As before (see Section 7.3), the incremental cost of operating the B Plant, 244-AR Vault, and tank farms for processing the capsule waste is assumed to be $\$ 1$ million. The cost of modifying the SAR to account for capsule waste processing is assumed to be the same as that for the direct blending case, viz., $\$ 1,200,000$.

The capsule waste blended into NCAW and/or CC waste is estimated to increase the number of canisters produced at HWVP by a maximum of 5 . At $\$ 500,000$ per canister, the incremental cost is $\$ 2.50 \mathrm{milli}$ ion. Thus, the total cost for the option: of processing capsules by removing the halides before blending with NCAW and/or CC waste is $\$ 14.9$ million in FY 1990 dollars.

\subsubsection{Hanford Heste Vitrification Plant Campaign Specifically for Capsules}

If it is impossible to blend the capsule material with either NCAW or CC waste, a special campaign could be run in the HWVP. Whether or not the halides are removed from the cesium and strontium will affect the total amount of glass produced and the resulting costs. As described in Section 4.1, if the halides are kept with the cesium and strontium, as many as 133 canisters could be produced. Costs are estimated to be on the order of 571.4 million for this case. If the halides are separated from the cesium and strontium, approximately 45 canisters would be produced at a cost of $\$ 32.7$ million. These costs are estimated based on initial WESF operations: $\$ 4.9 \mathrm{million}$ to disassemble the capsules and remove the salts and $\$ 5.3$ million for halide removal operations, followed by vitrification and disposal at $\$ 500,000$ per canister. These costs were presented in detail earlier in Section 7.0. 


\subsubsection{Hanford Waste Vitrification Plant Modifications}

The cost for modifying a laydown area and obtaining the equipment described in Section 6.3 is estimated to be $\$ 8.8$ million. This cost includes the engineering required to modify the current design, and reflects the costs for modifying the laydown area on the east side of the facility. Costs for modifying the laydown area on the west side would be greater because of the need for additional piping runs and other engineered features in this more complex area. The west laydown area may be preferable because of the masterslave manipulator transport paths within the vitrification facility. Modification of one of the laydown areas is not feasible without providing the laydown area space elsewhere in the facility. If the vitrification building is lengthened to provide this space, the incremental cost per foot is $\$ 1.2$ million. If the process cell Tayout is modified to provide this space without increasing the footprint, the additional cost will be at least $\$ 4.0$ million. Additional operating costs will be incurred if this is implemented. Life cycle cost impacts would have to be evaluated to determine the overall cost impact. The minimum cost for modifying the HWVP to vitrify the capsule waste is estimated at $\$ 13$ million.

Three options exist for subsequent vitrification operations. The lowcost option is to blend the capsule contents with pretreated NCAW and/or CC waste as it is brought into the plant. This option will result in an estimated increase of five canisters and a total cost of $\$ 20.4$ million, which includes costs for the previously discussed HWVP modifications and activities to remove the salts from the capsules ( $\$ 4.9$ million). Salt removal costs are considered here to be the same in HWVP as in WESF. The second option is to include the separation of the halides from the cesium and strontium in the flowsheet, followed by vitrification of the cesium and strontium in a separate campaign. Approximately 45 canisters would be produced, based on the concentration limit imposed by strontium (1.6 wt\% SrO) on the glass. Total process costs are estimated to be $\$ 45.6$ million. The third and most costly option is to vitrify the capsule material as a separate HWVP campaign without first separating the halides. Approximately 133 canisters would be produced at a total estimated cost of $\$ 84.5$ million. 
WHC-EP-0460

This page intentionaliy left blank. 


\subsection{SCHEDULE}

The schedule for performing the two options of blending the capsules with NCAW and/or CC waste is given in Figure 8-1. The schedule includes the time required for completing activities such as preparing the WESF cells, ordering equipment, installing equipment, ordering chemicals, and modifying the SAR. It should be pointed out that some of these activities will be carried out simultaneously.

Also illustrated in Figure 8-1 are the schedules for processing NCAW, neutralized cladding removal waste (NCRW), Plutonium Finishing Plant (PFP) waste, and $C C$ waste in $B$ Plant and HWVP. As shown by the figure, the schedule for processing capsule waste coincides with the processing of NCAW in the B Plant and the startup of HWVP operations with NCAW processing. The present schedule for the blending of capsule waste with NCAW assumes return of the capsules to WESF from organizations leasing some of the capsules, and preparation of any required National Environmental Policy Act (NEPA) documentation occurring before December 1996. This is an aggressive schedule that is driven by the HWVP schedule. To maximize the opportunity to blend the capsule waste with the planned HWVP feed streams, a decision to vitrify the capsule waste must be made soon. The engineering study will be the basis for making this decision and therefore, the engineering study must be initiated very soon. 
Figure 8-1. Schedule for Blending the Capsules with Neutralized Current Acid Waste.

\section{Calendar Year}

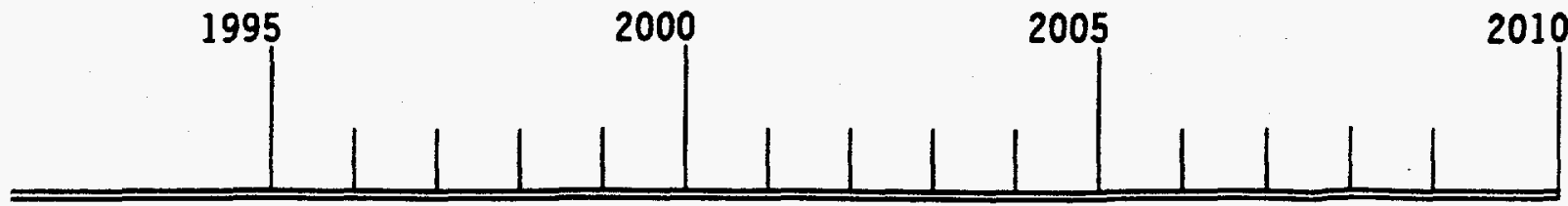

\section{Plant Process}

HWVP

processing

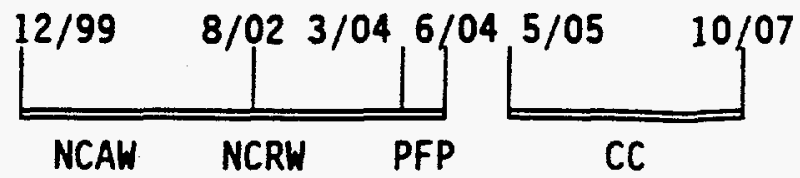

B Plant processing

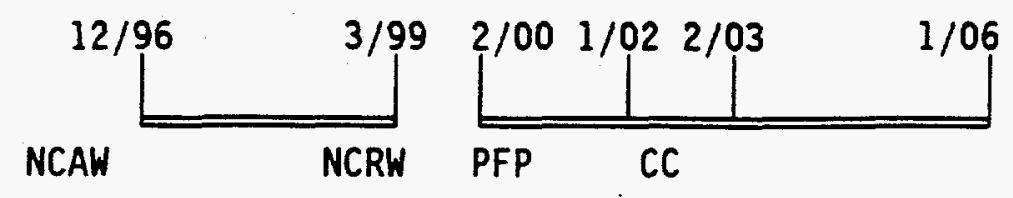

Direct $\mathrm{CsCl} / \mathrm{SrF}_{2}$ blending into

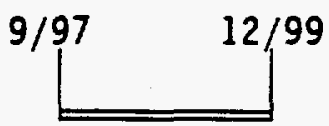

NCAW

Process capsules and blend cesium and

$12 / 96$

$12 / 99$ strontium with NCAW

$12 / 98$

NEPA documentation

(Start FY 1992) 


\subsection{REFERENCES}

Bates, S. 0., 1987, "Interim Milestone HWVP-87-V110202C - Report on FY87 Glass Variability Testing Conducted for the Hanford Waste Vitrification Program," Letter report prepared for Westinghouse Hanford Company by Pacific Northwest Laboratory, Richland, Washington.

Bray, L. A., et al. 1984, Experimental Data Development to Support the Selection of a Treatment Process for West Valley Alkaline Supernate, PNL-4969, Pacific Northwest Laboratory, Richland, Washington.

Bryan, G. H., 1987, Cesium Chloride Compatibility Testing Progran: Annual Report for Fiscal Year 1986, PNL-6170, Pacific Northwest Laboratory, Richland, Washington.

Colburn, R. P., 1990, Hanford Waste Vitrification Plant Preliminary Waste Form and Canister Description--Fiscal Year 1990 Update, WHC-EP-0376, Westinghouse Hanford Company, Richland, Washington.

DOE, 1987, Final Environmental Impact Statement, Disposal of Hanford Defense High-Level, Transuranic and Tank Wastes, DOE/EIS-0113, U.S. Department of Energy, Washington, D.C.

DOE, 1989, Waste Acceptance Preliminary Specifications for the Defense Waste Processing Facility High-Level Waste Form, Revision 1, DoW/RW-0260 (PE-03), U.S. Department of Energy-Office of Civilian Radioactive Waste Management, Washington, D.C.

DOE-RL, 1987, Manford Waste Management Plan, DOE/RL-87-13, U.S. Department of Energy-Richland Operations Office, Richland, Washington.

Ecology, EPA, and DOE, 1990, Hanford Federal Facility Agreement and Consent Order, Vol. 1 and 2, Washington State Department of Ecology, U.S. Environmental Protection Agency, and U.S. Department of Energy, $01 y$ ypia, Washington.

Elmore, M. R., 1986, "Impact of Decay Heat Load on Equilibrium Glass Temperature" (1etter to D. H. Siemens, dated May 21, 1986), Pacific Northwest Laboratory, Richland, Washington.

Elmore, M. R., and G. A. Jensen, 1990, "Materials Selection for Embedded Piping, Process Vessels and Associated Components in the Hanford Waste Vitrification Plant," HWVP-90-1.2.2.04.16B, Pacific Northwest Laboratory, Richl and, Washington.

Fournier, R. D., and J. J. Rowe, 1977, "The Solubility of Amorphous Silica in Water at High Temperatures and Pressures, "American Mineralogy 62:1052-1056 [Location].

Fullam, H. T., 1971, Physical Property Measurements on Cesium Chloride and Cesium Chloride Alkali Metal Chloride Systems, BNWL-B-74, Battelle Northwest Laboratories, Richland, Washington. 
Fullam, H. T., 1972, Compatibility of Cesium Chloride and Strontium Fluoride with Containment Materials, BNWL-1673, Battelle Northwest Laboratories, Richland, Washington.

Fullam, H. T., 1977, Strontium-90 Fluoride Data Sheet, BNWL-2284, Battelle Northwest Laboratories, Richland, Washington.

Fullam, H. T., 1981, Compatibility of Strontium-90 Fluoride with Containment Materials at Elevated Temperatures, PNL-3833, Pacific Northwest Laboratory, Richland, Washington.

Goles, R. W., and C. M. Andersen, 1986, "LFCM Emission and Offgas System Performance for Feed Component Cesium," In Proc. of Spectrum '86, Niagara'Falls, New York, Eds., J. M. Pope, I. M. Leonard, and E. J. Mayer, Vol. I, Pp. 1,068-1,084.

Goles, R. W., and C. M. Andersen, 1987, "HWVP Melter Offgas System Evaluation," HWVP-87-V110305A/PRMC-SC-350-00-049 (uncleared internal letter report prepared for Westinghouse Hanford Company), Pacific Northwest Laboratory, Richland, Washington.

Goles, R. W., and R. K. Nakaoka, 1990, Hanford Waste Vitrification Progran Pilot-Scale Ceramic Melter Test 23, PNL-7142, Pacific Northwest Laboratory, Richland, Washington.

Harrison-Giesler, D. J., 1990, Personal communication with J. L. Nelson, August 22, 1990.

Holton, L. K., Jr., R. D. Dierks, R. W. Goles, Y. B. Katayama, J. E. Surma, and N. M. Thomas, 1988, "Operating Experience in a Radioactive Liquid-Fed Ceramic Melter Vitrification Facility," In Proc. of the Symposium on Waste Management 1988, Tucson, Arizona, Eds. R. G. Post, and M. E. Wacks, Vol. II, pp. 217-227.

ORNL, 1988, Strontium-90 Processing Procedure, ORNL-IP-514, Radioactive Processing Group, Isotope Processing Department, Oak Ridge National Laboratory, Oak Ridge, Tennessee.

Oversby, V. M., 1990, Personal Communication with J. L. Nelson, August 22, 1990.

PNL, 1984, "Assessment of the Use of Cesium from West Valley Supernate for the Production of FRG Glass Canisters," PNL letter report, Pacific Northwest Laboratory, Richland, Washington.

Ryss, I. G., 1956, The Chemistry of Fluorine and its Inorganic Compounds, AEC-TR-3927, Part 1 [Publisher, Location].

Sewe11, R. G., 1986, Waste Encapsulation and Storage Facility (WESF) Safety Analysis Report (SAR), SD-WM-SAR-005, Rev. 6, Rockwell Hanford Operations, Richland, Washington.

Simons, J. H., ed. 1950, Fluorine Chemistry, Vol. I, Academic Press, New York, New York. 
Volf, M. B., 1984, Chemical Approach To Glass, Vol. 7 of Glass Science and Technology, El sevier, New York.

Watrous, R. A., and D. D. Chen, 1978, Disposal of Strontium and Cesium Capsules in Geologic Media - An Analysis of Technical Feasibility, RHO-LD-51, Rockwel1 Hanford Operations, Richland, Washington.

Weast, R. C., M. J. Astle, and W. H. Beyer, eds. 1987, CRC Handbook of Chemistry and Physics, CRC Press Inc., Boca Raton, Florida.

WHC, 1989, Hanford Waste Vitrification Plant Technical Data Package, Section 13, Rev 4C, "Miscellaneous Process Data," SD-HWV-DP-001, Westinghouse Hanford Company, Richland, Washington. 
WHC-EP-0460

This page intentionally left blank. 
APPENDIX A

REQUIREMENTS FOR REPOSITORY DISPOSAL OF DEFENSE

HIGH-LEVEL WASTE 
WHC-EP-0460

This page intentionally left blank.

A-2 
Both commercial spent fuel and defense high-level wastes have been identified by the Nuclear Waste Policy Act as materials to be disposed of in a geologic repository. Chapter 10, Part 60 of the Code of Federal Regulations (10 CFR 60) identifies specific requirements for the characteristics of all wastes to be disposed of in a geologic repository. The Waste Acceptance Preliminary Specifications (WAPS) for the Defense Waste Processing Facility (DWPF) have been developed to provide guidance to the DWPF as to the legaliy required characteristics of the waste form, and the required characteristics to ensure that the DWPF product can be safely handled at the repository.

The WAPS contain 21 individual specifications. Of these, 12 are directly mandated by 10 CFR 60 for both spent fuel and defense high-level waste. The titles of the specifications and the applicable subpart citation from 10 CFR 60 are shown below.

$\begin{array}{lll}1.4 & \text { Chemical and Phase Stability } & 135(a)(2) \\ 2.1 & \text { Material } & 135(a)(1) \\ 2.2 & \text { Fabrication and Closure } & 135(c)(1) \\ 2.3 & \text { Identification and Labeling } & 135(b)(4) \\ 3.1 & \text { Free Liquid } & 135(b)(2) \\ 3.2 & \text { Gas } & 135(b)(2) \\ 3.3 & \text { Explosiveness, Pyrophoricity, Combustibility } & 135(b)(1),(c)(3) \\ 3.4 & \text { Organic Material } & 135(a)(1) \\ 3.9 & \text { Chemical Compatibility } & 135(a)(1) \\ 3.10 & \text { Subcriticality } & 131(b)(7) \\ 3.12 & \text { Drop Test } & 134(c)(1),(c)(2) \\ 4.0 & \text { Quality Assurance } & 150\end{array}$

The remaining nine specifications are not directly mandated by federal law, but are required by the candidate repository project as a part of the repository performance assessment evaluations, or to ensure that the remote handling capability at the repository will be compatible with the waste form. A discussion of these specifications is provided below.

Specifications 1.1 (Chemical) and 1.2 (Radionuclide Inventory) are required by the repository project as a part of the performance assessment. The repository is required by 10 CFR 60 Subparts 113 and $134(a)(2)$ to account for all chemical and radiochemical species contained by the repository and to ensure that none of these species impair the repository waste isolation capability. Additionally, the repository must maintain an accounting of all radionuclides contained in the repository in order to comply with accountability requirements implicit in 10 CFR 60 Subpart (a)(ii)(B). To achieve this, the repository project requires that documentation be provided for the radionuclide content of all wastes. For spent fuel this will be achieved by ORIGEN calculations using fuel manufacturing records, burnup records, and storage records. Such records exist for virtually all fuels in 
the United States, except for the very oldest. Defense high-level waste is required to meet the same accountability requirements as spent fuel, for the same reasons.

Compliance with these requirements is more problematic for defense highlevel waste producers because the waste materials are derived from more complicated chemical processes (reprocessing), blended so that all discrete identity is lost (storage) and then remanufactured into a completely new waste form (vitrification, for DWPF and Hanford Waste Vitrification PIant [HWVP]). Nonetheless, the same requirements apply to spent fuel as for defense highlevel waste, even though compliance techniques will differ.

Specification 1.3 (Radionuclide Release), as currently written, is used to characterize the intrinsic interactions of the waste form with hydrothermal environments. Spent fuel undergoes hydrothermal radionuclide release testing as a part of the repository performance assessment studies. Defense highlevel waste will undergo similar testing for the same reasons. Since defense high-level waste has greater potential for inhomogeneity than does spent fuel, the high-level waste producers must conduct testing on a wider base of compositions, reflecting the greater variability of the product. Although the required data for radionuclide release is greater for defense high-level waste than the spent fuel, the need for such data is applied equally for the two waste forms.

Specification 3.5 (Free Volume) was promulgated by the Basalt Waste Isolation Project (BWIP). The BWIP required that the contents of the waste package (the waste form) provide support for the waste package itself against the hydrostatic head of the repository. For spent fuel, this support will be provided by the arrangement of the fuel rods within the waste package. For defense high-level waste, this will be provided by the vitrified waste form in an essentially completely full canister. Although the need for structural support does not equate to a "free volume" specification for spent fuel, the need for this characteristic is common between the two waste forms.

Specification 3.6 (Removable Radioactive Contamination) has no corresponding constraint for spent fuel. The repository project will use separate surface handling facilities for spent fuel and defense high-level wastes. The project wishes to use contact maintenance procedures for defense waste handling equipment, but realizes that this cannot be achieved for spent fuel.

Specification 3.7 (Heat Generation) and 3.8 (Maximum Dose Rates) correspond to the spent fuel acceptance specification that the repository must be capable of accepting 5-year-young spent fuel of 33,000 MWD/MTU burnup (Generic Requirements for a Mined Geologic Disposal System). This spent fuel specification essentially defines an upper limit for heat generation and dose rate. Similarly, such specifications have been established for defense high- Tevel waste.

Specification 3.11 (Dimensions) and 3.13 (Handling Features) are established to ensure that the defense high-level waste forms can be accommodated by the repository handling equipment. Similar handling envelopes have been defined for spent fuel. 


\section{APPENDIX B}

EFFECTS OF CESIUH CHLORIDE AND STROMTIUM FLUORINE CAPSULE ADDITION TO NEUTRALIZED CURRENT ACID WASTE GLASS

B-1 


\section{WHC-EP-0460}

This page intentionally left blank. 
Table B-1. Impact of Cesium Chloride and Strontium Fluorine Capsules Added to Neutralized Current Acid Waste/Hanford Waste Vitrification Plant Glass. (sheet 1 of 2)

\begin{tabular}{|c|c|c|}
\hline $\begin{array}{l}\text { Number of canisters of glass } \\
\text { from NCAW processing }\end{array}$ & 480 canisters & $\begin{array}{l}\text { per Bob Watrous } \\
\text { (telecon } 6 / 1 / 90 \text { ) }\end{array}$ \\
\hline $\begin{array}{l}\text { wt\% } \mathrm{Cs}_{2} \mathrm{O} \text { in NCAW glass } \\
\text { (reference case) }\end{array}$ & 0.15 wt\% & HWVP TDP \\
\hline $\mathrm{kg}$ of glass per canister & $1,650 \mathrm{~kg}$ & HWVP TDP \\
\hline Total quantity of glass & $792,000 \mathrm{~kg}$ & Calculated \\
\hline Quantity of $\mathrm{Cs}_{2} \mathrm{O}$ & $1,188 \cdot \mathrm{kg}$ & Calculated \\
\hline $\begin{array}{l}\text { Quantity of cesium in NCAW } \\
\text { glass canisters }\end{array}$ & $1,121 \mathrm{~kg}$ & Calculated \\
\hline Number of capsules of CsCl & 1,349 capsules & WHC-EP-0195 \\
\hline Quantity of CsCl per capsule & $2.7 \mathrm{~kg}$ & $\begin{array}{l}\text { Per G. Tingey } \\
\text { (telecon w/ } \\
\text { R. D. Peters } 6 / 1 / 90 \text { ) }\end{array}$ \\
\hline Total quantity of $\mathrm{CsCl}$ & $3,642 \mathrm{~kg}$ & Calculated \\
\hline $\begin{array}{l}\text { Quantity of cesium in } \\
\text { capsules }\end{array}$ & $2,875 \mathrm{~kg}$ & Calculated \\
\hline $\begin{array}{l}\text { Quantity of cesium in NCAW } \\
\text { glass with capsules added }\end{array}$ & $3,996 \mathrm{~kg}$ & Calculated \\
\hline $\begin{array}{l}\text { wt\% } \mathrm{CS}_{2} \mathrm{O} \text { in NCAW glass with } \\
\text { capsules added }\end{array}$ & 0.53 wt\% & Calculated \\
\hline $\begin{array}{l}\text { wt\% Sro in NCAW glass } \\
\text { (reference case) }\end{array}$ & 0.1 wt\% & HWVP TDP \\
\hline Total quantity of Sro & $792 \mathrm{~kg}$ & Calculated \\
\hline $\begin{array}{l}\text { Quantity of strontium in } \\
\text { NCAW glass canisters }\end{array}$ & $670 \mathrm{~kg}$ & Calculated \\
\hline Number of capsules of $\mathrm{SrF}_{2}$ & 636 capsules & WHC-EP-0195 \\
\hline Quantity of $\mathrm{SrF}_{2}$ per capsule & $2.7 \mathrm{~kg}$ & $\begin{array}{l}\text { Per G. Tingey } \\
(\text { telecon } w / \\
\text { R. D. Peters } 6 / 1 / 90 \text { ) } \\
\end{array}$ \\
\hline Total quantity of $\mathrm{SrF}_{2}$ & $1,717 \mathrm{~kg}$ & Calculated \\
\hline $\begin{array}{l}\text { Quantity of strontium in } \\
\text { capsules }\end{array}$ & $1,198 \mathrm{~kg}$ & Calculated \\
\hline $\begin{array}{l}\text { Quantity of strontium in } \\
\text { NCAW glass with capsules } \\
\text { added }\end{array}$ & $1,867 \mathrm{~kg}$ & Calculated \\
\hline
\end{tabular}


Table B-1. Impact of Cesium Chloride and Strontium Fluorine Capsules Added to Neutralized Current Acid Waste/Hanford Waste Vitrification Plant Glass. (sheet 2 of 2)

\begin{tabular}{|c|c|c|}
\hline $\begin{array}{l}\text { wt\% SrO in NCAW glass with } \\
\text { capsules added }\end{array}$ & $0.28 w t \%$ & Calculated \\
\hline $\begin{array}{l}\text { wt\% chlorine in NCAW glass } \\
\text { (reference case) }\end{array}$ & $0.075 w t \%$ & HWVP TDP \\
\hline $\mathrm{kg}$ of glass per canister & $1,650 \mathrm{~kg}$ & HWVP TDP \\
\hline Total quantity of glass & $792,000 \mathrm{~kg}$ & Calculated \\
\hline $\begin{array}{l}\text { Quantity of chlorine in NCAW } \\
\text { glass canisters }\end{array}$ & $594 \mathrm{~kg}$ & Calculated \\
\hline Number of capsules of $\mathrm{CsCl}$ & 1,349 capsules & WHC-EP-0195 \\
\hline Quantity of $\mathrm{CsCl}$ per capsule & $2.7 \mathrm{~kg}$ & $\begin{array}{l}\text { Per G. Tingey } \\
\text { (telecon } w / \\
\text { R. D. Peters } 6 / 1 / 90 \text { ) }\end{array}$ \\
\hline Total quantity of $\operatorname{CsCl}$ & $3,642 \mathrm{~kg}$ & Calculated \\
\hline $\begin{array}{l}\text { Quantity of chlorine in } \\
\text { capsules }\end{array}$ & $767 \mathrm{~kg}$ & Calculated \\
\hline $\begin{array}{l}\text { Quantity of chlorine in NCAW } \\
\text { glass with capsules added }\end{array}$ & $1,361 \mathrm{~kg}$ & Calculated \\
\hline $\begin{array}{l}\text { wt\% chlorine in NCAW glass } \\
\text { with capsules added }\end{array}$ & $0.17 w t \%$ & Calculated \\
\hline $\begin{array}{l}\text { wt\% fluorine in NCAW glass } \\
\text { (reference case) }\end{array}$ & 0.3 wt\% & HWVP TDP \\
\hline Total quantity of fluorine & $2,376 \mathrm{~kg}$ & Calculated \\
\hline Number of capsules of $\mathrm{SrF}_{2}$ & 636 capsules & WHC-EP-0195 \\
\hline Quantity of $\mathrm{SrF}_{2}$ per capsule & $2.7 \mathrm{~kg}$ & $\begin{array}{l}\text { Per G. Tingey } \\
\text { (telecon w/ } \\
\text { R. D. Peters } 6 / 1 / 90 \text { ) }\end{array}$ \\
\hline Total quantity of $\mathrm{SrF}_{2}$ & $1,717 \mathrm{~kg}$ & Calculated \\
\hline $\begin{array}{l}\text { Quantity of fluorine in } \\
\text { capsules }\end{array}$ & $19 \mathrm{~kg}$ & Calculated \\
\hline $\begin{array}{l}\text { Quantity of fluorine in NCAW } \\
\text { glass with capsules added }\end{array}$ & $2,895 \mathrm{~kg}$ & Calculated \\
\hline $\begin{array}{l}\text { wt\% fluorine in NCAW glass } \\
\text { with capsules added }\end{array}$ & $0.37 w t \%$ & Calculated \\
\hline
\end{tabular}


Table B-2. Impact of Curie and Watt Increases on Neutralized Current Acid Waste/Hanford Waste Vitrification Plant Glass.

\begin{tabular}{|l|c|c|c|c|}
\hline \multicolumn{4}{|c|}{ 1. Current NCAW/HWVP glass curie and watt contents (Source: } \\
WHC 1989). \\
\hline Case & $\begin{array}{c}\text { Curies } \\
(\text { Ci/gal) }\end{array}$ & $\begin{array}{c}\text { Curies per } \\
\text { canister }\end{array}$ & $\begin{array}{c}\text { Watts } \\
\text { (W/gal) }\end{array}$ & $\begin{array}{c}\text { Watts per } \\
\text { canister }\end{array}$ \\
\hline Nominal & 38.6 & 134,729 & 0.109 & 380 \\
\hline Maximum & 84.22 & 93,890 & 0.24 & 838 \\
\hline
\end{tabular}

\begin{tabular}{|l|c|}
\hline Input data & \\
\hline Gallons NCAW/Canister & $3,490 \mathrm{gal}$ \\
\hline Ib waste oxides per gal NCAW & $0.26 \mathrm{lb}$ \\
\hline $\mathrm{kg}$ glass per canister & $1,650 \mathrm{~kg}$ \\
\hline Reference glass waste loading & $25 \%$ \\
\hline Total number of NCAW canisters & 480 \\
\hline Assumed time of $\mathrm{Ci}$ and W estimate & $1998-2002$ \\
\hline
\end{tabular}

\begin{tabular}{|l|c|c|c|c|}
\hline \multicolumn{5}{|c|}{$\begin{array}{l}\text { Approximate curie and watt content of } \mathrm{CSCl} \text { and } \mathrm{SrF}_{2} \text { capsules } \\
\text { (Source: IDB: DOE/RW-0006, REV. 5). }\end{array}$} \\
\hline \multicolumn{1}{|c|}{ Case } & Total curies & Total curies & Total watts & Total watts \\
\hline Year & $1 / 1 / 95$ & $1 / 1 / 10$ & $1 / 1 / 95$ & $1 / 1 / 10$ \\
\hline $\mathrm{CSCl}$ & $90,000,000$ & $63,000,000$ & 222,128 & 157,198 \\
\hline $\mathrm{SrF}_{2}$ & $51,000,000$ & $36,000,000$ & 173,584 & 123,074 \\
\hline $\begin{array}{l}\text { Number of } \mathrm{CSCl}_{1} \text { capsules } \\
\text { Number of SrF }\end{array}$ capsules & & 1,349 \\
\end{tabular}

\begin{tabular}{|l|c|c|c|c|}
\hline \multicolumn{5}{|c|}{ 3. Estimated NCAW/HWVP glass curie and watt contents following } \\
blending of CsC1 and SrF 2 capsules with NCAW. \\
\hline \multicolumn{1}{|c|}{ Case } & Curies/can & Watts/can & Curies/can & Watts/can \\
\hline Date & $1 / 1 / 10$ & $1 / 1 / 10$ & $1 / 1 / 00$ & $1 / 1 / 00$ \\
\hline Nominal & $<341,000$ & $<964$ & 267,440 & 1,066 \\
\hline Maximum & $<500,000$ & $<1,422$ & 554,690 & 1,524 \\
\hline
\end{tabular}


WHC-EP-0460

This page intentionally left blank.

B-6 

WHC-EP-0460

This page intentionally left blank. 
Table C-1. Impact of Cesium Chloride and Strontium Fluorine Capsules Added to Complexant Concentrate/Hanford Waste Vitrification Plant Glass. (sheet 1 of 2)

\begin{tabular}{|c|c|c|}
\hline $\begin{array}{l}\text { Number of canisters of glass from CC } \\
\text { processing }\end{array}$ & 650 canisters & HWVP TDP \\
\hline wt\% $\mathrm{Cs}_{2} \mathrm{O}$ in $\mathrm{CC}$ glass (reference case) & 0.12 wt\% & HWVP-87-V110201A \\
\hline kg of glass per canister & $1,650 \mathrm{~kg}$ & HWVP TDP \\
\hline Total quantity of glass & $1,072,500 \mathrm{~kg}$ & Calculated \\
\hline Quantity of $\mathrm{Cs}_{2} \mathrm{O}$ & $1,287 \mathrm{~kg}$ & Calculated \\
\hline Quantity of $C S$ in $C C$ glass canisters & $1,214 \mathrm{~kg}$ & Calculated \\
\hline Number of capsules of $\mathrm{CsCl}$ & 1,349 capsules & WHC-EP-0195 \\
\hline Quantity of $\mathrm{CsCl}$ per capsule & $2.7 \mathrm{~kg}$ & $\begin{array}{l}\text { Per G. Tingey } \\
\text { (telecon W/ } \\
\text { R. D. Peters } \\
6 / 1 / 90 \text { ) }\end{array}$ \\
\hline Total quantity of $\mathrm{CsCl}$ & $3,642 \mathrm{~kg}$ & Calculated \\
\hline Quantity of Cs in capsules & $2,875 \mathrm{~kg}$ & Calculated \\
\hline $\begin{array}{l}\text { Quantity of CS in CC glass with } \\
\text { capsules added }\end{array}$ & $4,089 \mathrm{~kg}$ & Calculated \\
\hline $\begin{array}{l}\text { wt\% } \mathrm{Cs}_{2} \mathrm{O} \text { in } \mathrm{CC} \text { glass with capsules } \\
\text { added }\end{array}$ & $0.40 w t \%$ & Calculated \\
\hline wt\% Sro in CC glass (reference case) & 0 wt\% & HWVP-87-V110201A \\
\hline Total quantity of Sro & $0 \mathrm{~kg}$ & Calculated \\
\hline $\begin{array}{l}\text { Quantity of strontium in CC glass } \\
\text { canisters }\end{array}$ & $0 \mathrm{~kg}$ & Calculated \\
\hline Number of capsules of $\mathrm{SrF}_{2}$ & 636 capsules & WHC-EP-0195 \\
\hline Quantity of $\mathrm{SrF}_{2}$ per capsule & $2.7 \mathrm{~kg}$ & $\begin{array}{l}\text { Per G. Tingey } \\
\text { (telecon w/ } \\
\text { R. D. Peters } \\
6 / 1 / 90 \text { ) }\end{array}$ \\
\hline Total quantity of $\mathrm{SrF}_{2}$ & $1,717 \mathrm{~kg}$ & Calculated \\
\hline Quantity of strontium in capsules & $1,198 \mathrm{~kg}$ & Calculated \\
\hline $\begin{array}{l}\text { Quantity of strontium in CC glass } \\
\text { with capsules added }\end{array}$ & $1,198 \mathrm{~kg}$ & Calculated \\
\hline
\end{tabular}


Table C-1. Impact of Cesium Chloride and Strontium Fluorine Capsules Added to Complexant Concentrate/Hanford Waste Vitrification Plant Glass. (sheet 2 of 2)

\begin{tabular}{|c|c|c|}
\hline $\begin{array}{l}\text { wt\% SrO in CC glass with capsules } \\
\text { added }\end{array}$ & $0.13 w t \%$ & Calculated \\
\hline wt\% Cl in CC glass (reference case) & 0.25 wt\% & HWVP-87-V110201A \\
\hline $\mathrm{kg}$ of glass per canister & $1,650 \mathrm{~kg}$ & HWVP TDP \\
\hline Total quantity of glass & $792,000 \mathrm{~kg}$ & Calculated \\
\hline $\begin{array}{l}\text { Quantity of chlorine in } \mathrm{CC} \text { glass } \\
\text { canisters }\end{array}$ & $1,980 \mathrm{~kg}$ & Calculated \\
\hline Number of capsules of $\mathrm{CsCl}$ & 1,349 capsules & WHC-EP-0195 \\
\hline Quantity of $\mathrm{CsCl}$ per capsule & $2.7 \mathrm{~kg}$ & $\begin{array}{l}\text { Per G. Tingey } \\
\text { (telecon } w / R \text {. D. } \\
\text { Peters } 6 / 1 / 90 \text { ) }\end{array}$ \\
\hline Total quantity of $\mathrm{CsCl}$ & $3,642 \mathrm{~kg}$ & Calculated \\
\hline Quantity of chlorine in capsules & $767 \mathrm{~kg}$ & Calculated \\
\hline $\begin{array}{l}\text { Quantity of chlorine in } \mathrm{CC} \text { glass } \\
\text { with capsules added }\end{array}$ & $2,747 \mathrm{~kg}$ & Calculated \\
\hline $\begin{array}{l}\text { wt\% chlorine in CC glass with } \\
\text { capsules added }\end{array}$ & $0.35 w t \%$ & Calculated \\
\hline $\begin{array}{l}\text { wt\% fluorine in CC glass (reference } \\
\text { case) }\end{array}$ & $0.05 w t \%$ & HWVP-87-V110201A \\
\hline Total quantity of fluorine & $396 \mathrm{~kg}$ & Calculated \\
\hline Number of capsules of $\mathrm{SrF}_{2}$ & 636 capsules & WHC-EP-0195 \\
\hline Quantity of $\mathrm{SrF}_{2}$ per capsule & $2.7 \mathrm{~kg}$ & $\begin{array}{l}\text { Per G. Tingey } \\
\text { (telecon } w / R \text {. D. } \\
\text { Peters } 6 / 1 / 90 \text { ) } \\
\end{array}$ \\
\hline Total quantity of $\mathrm{SrF}_{2}$ & $1,717 \mathrm{~kg}$ & Calculated \\
\hline Quantity of fluorine in capsules & $519 \mathrm{~kg}$ & Calculated \\
\hline $\begin{array}{l}\text { Quantity of fluorine in CC glass } \\
\text { with capsules added }\end{array}$ & $915 \mathrm{~kg}$ & Calculated \\
\hline $\begin{array}{l}\text { wt\% fluorine in CC glass with } \\
\text { capsules added }\end{array}$ & $0.12 w t \%$ & Calculated \\
\hline
\end{tabular}


Table C-2. Impact of Curie and Watt Increases on Complexant Concentrate/Hanford Waste Vitrification Plant Glass.

1. Current CC/HWVP glass curie and watt contents (Source: DOE RH-0184, volume 1 of 6, Table 3.4.5).

\begin{tabular}{|c|c|c|}
\hline & Curies per canister & Watts per canister \\
\hline & 230 & 1 \\
\hline
\end{tabular}

\begin{tabular}{|l|c|}
\hline $\mathrm{kg}$ glass per canister & $1,650 \mathrm{~kg}$ \\
\hline Reference glass waste loading & $25 \%$ \\
\hline Total number of CC canisters & 650 Canisters \\
\hline Assumed time of Ci and watt estimate & $1998-2002$ \\
\hline
\end{tabular}

2. Approximate curie and watt content of $\mathrm{CsCl}$ and $\mathrm{SrF}_{2}$ capsules (Source: IDB: DOE/RW-0006, REV. 5).

\begin{tabular}{|l|c|c|c|c|}
\hline \multicolumn{1}{|c|}{ Case } & Total curies & Total curies & Total watts & Total watts \\
\hline Year & $1 / 1 / 95$ & $1 / 1 / 10$ & $1 / 1 / 95$ & $1 / 1 / 10$ \\
\hline $\mathrm{CsCl}$ & $90,000,000$ & $63,000,000$ & 222,128 & 157,198 \\
\hline $\mathrm{SrF}_{2}$ & $51,000,000$ & $36,000,000$ & 173,584 & 123,074 \\
\hline $\begin{array}{l}\text { Number of } \mathrm{CsCl}_{\text {Number of } \mathrm{SrF}_{2} \text { capsules }} \\
\text { Napsules }\end{array}$ & $\begin{array}{r}1,349 \\
636\end{array}$ \\
\hline
\end{tabular}

3. Estimated CC/HWVP glass curie and watt contents following blending of $\mathrm{CsCl}$ and $\mathrm{SrF}_{2}$ capsules with $\mathrm{CC}$.

\begin{tabular}{|l|c|c|c|c|}
\hline \multicolumn{1}{|c|}{ Case } & Curies/can & Watts/can & Curies/can & Watts/can \\
\hline Year & $1 / 1 / 10$ & $1 / 1 / 10$ & $1 / 1 / 95$ & $1 / 1 / 95$ \\
\hline Nominal & 152,538 & 431 & 217,153 & 609 \\
\hline
\end{tabular}


WHC-EP-0460

This page intentionally left blank.

C-6 